\title{
A REVISION OF THE TRIASSIC AND JURASSIC TETRAPOD FOOTPRINTS OF ARGENTINA AND A NEW APPROACH ON THE AGE AND MEANING OF THE BOTUCATU FORMATION FOOTPRINTS (BRAZIL)
}

\author{
GIUSEPPE LEONARDI* and FRANCISCO HENRIQUE DE OLIVEIRA**
}

\begin{abstract}
RESUMO UMA REVISÃO DAS PEGADAS TRIÁSSICAS E JURÁSSICAS DE TETRÁPODES DA ARGENTINA E UMA NOVA ABORDAGEM SOBRE A IDADE E O SIGNIFICADO DAS PEGADAS DA FORMAÇÃO BOTUCATU (BRASIL). São expostos os resultados de uma expedição pela Argentina, durante a qual foi examinado o material icnoldgico argentino referente aos tetrápodes, do Carbonffero ao Pleistocene. São descritas, classificadas, ilustradas e revisadas, aqui, de maneira preliminar, apenas as icnofaunas argentinas de idade triássica e jurassica. Tais dados são comparados com as icnofaunas de tetrápodes da Formação Botucatu, no Estado de São Paulo. Esta icnofauna é de difícil classificação, posto que se trata de uma associação completamente nova. Deve ser mencionado que o material não é, em geral, de boa qualidade. As associações Triássicas da Argentina, representadas pelas localidades de Lãs Higueras, Campo de Ischigualasto, Quebrada Los Rastros, Rio Los Tarros-Sur Pagancillo e Los Menucos, são caracterizadas pela presença, em quantidades variáveis, de terápsides e poucos arcossauros, entre os quais predominam os tecodontes quadrúpedes. Os mamíferos são raros. Pelo contrátrio, na associação jurássica de Laguna Manantiales, há uma predominância dos mamíferos, acompanhada de quatro formas dinossaurianas, e ausência de terápsides e tecodontes quadrúpedes. A Formação Botucatu, nos arredores de Araraquara, possui uma icnofauna na qual predominam os mamíferos primitivos, acompanhados de poucos dinossauròides bfpedes e poucos terápsides atribuídos tentativamente a Tritylodontoidea. A comparação detalhada entre a estrutura das diversas associações permite atribuir a Formação Botucatu, pelos menos no Estado de São Paulo, ao Jurássico Inferior ou Médio.
\end{abstract}

Palavras-chaves: Pegadas de tetrápodes, Jurássico, Triássico, Formação Botucatu, Argentina, Brasil.

\begin{abstract}
A description and a revision of the Triassic (Las Higueras Ischigualasto, Quebrada Los Rastros, Rio Los Tarros-Sur Pagancillo and Los Menucos) and Jurassic (Estância Laguna Manantiales) tetrapod ichnofaunas of Argentina and of the Botucatu Formation at Araraquara (São Paulo, Brazil) are given. The structures of these ichno-associations are compared. The Triassic Argentinean ichnofaunas present therapsids and archosaurians, specially quadrupedal thecodonts. Mammals are very rare. In the Jurassic (Oxfordian) ichnofauna of Estância Laguna Manantiales, mammals, accompanied by four dinosaurian forms, predominate. There are not obviously either therapsids nor quadrupedal thecodonts. The Botucatu Formation, whose age was up to now uncertain and is herein discussed, presents at Araraquara a rich ichnofauna. This includes many mammals, a few biopedal dinosaurs and some theromorphoid footprints, tentatively attributed to Tritylodontoidea. The Botucatu Formation, at least in the outcrops of the State of São Paulo and particularly in the Araraquara area, might be put into a period of time between the Rhaetian and Middle Jurassic, with a greater probability for Lower Jurassic or the lowest section of the Middle Jurassic.
\end{abstract}

Keywords: Tetrapod footprints, Jurassic, Triassic, Botucatu Formation, Argentina, Brasil.

\section{ARGENTINEAN ICHNOFAUNAS Introduction As}

part of a program of summary and revision of all Latin American localities of fossil tetrapod footprints, one of the authors (G.L) travelled extensively throughout Argentina during late 1981.

Outcrops in several provinces were visited and nearly all ichnological material pertaining to tetrapods (Permian to Holocene) in the field and in scientific institutions throughout the country was analyzed (Fig. 1).

The following report presents the results of the expedition for Triassic and Jurassic ichnofaunas.

Los Menucos (Province of Rio Negro) One of authors (G.L.) was able to visit the quarries, specially those of the flagstones for sidewalks for around the city of Los Menucos, in the Patagonian "meseta" about $500 \mathrm{~km}$ west of Viedma. Some quarries, collectively referred to as "La Cantera Nueva" (The New Quarry) (PI. IV.A), almost always contain coarse, pinkish-yellow tuffaceous material of an unnamed formation attributed to the Upper Triassic (Norian-Lower Rhaetian). Only one set of unclassifiable thermorphoid footsprints was found.

About $2 \mathrm{~km}$ further north, in the Tscherig Ranch, the small quarries collectively referred to as "Cantera Tsherig" or "La Vieja" of the same formation and scattered over a broad area

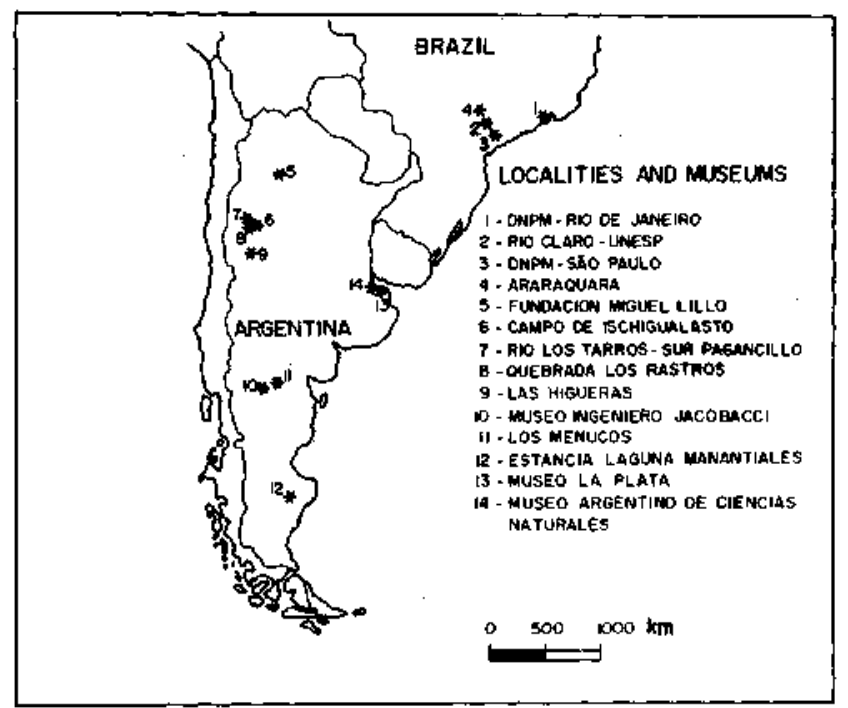

Figure 1 - Map of the localities and museums visited in Brazil and Argentina

Figura I - Mapa das localidades e dos museus visitados no Brasil e na Argentina

\footnotetext{
* CNPq/DNPM, SÉS Q, 801/B, CEP 70401, Brasflia, DF, Brasil

** Universidade de Brasflia, Q. 4, B I. C, casa 56, Cruzeiro Velho, CEP 70640, Brasflia, DF, Brasil
} 


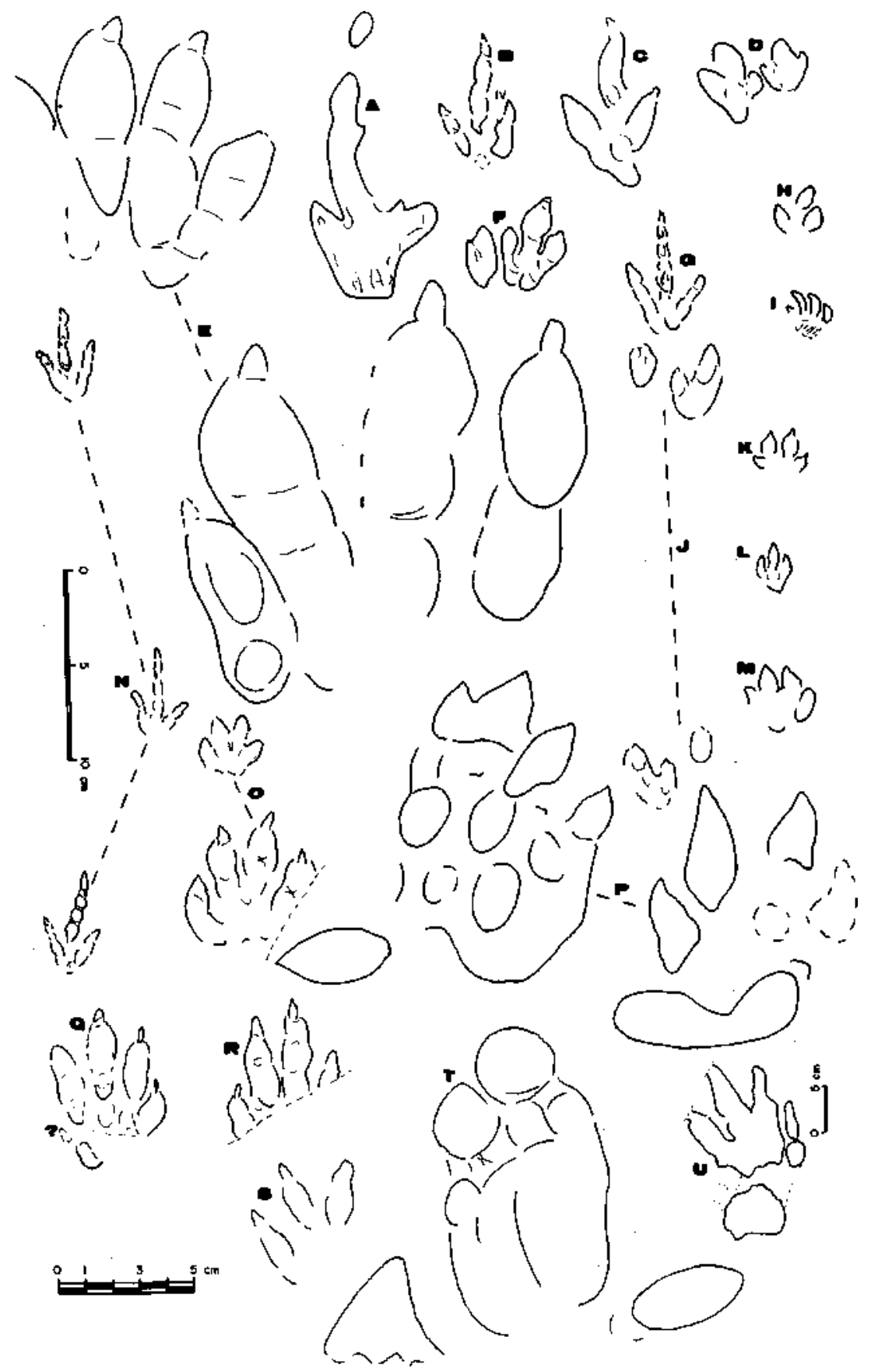

Plate I-Archosaurian footprints from Argentina.

A-B-C-G-N: Wildesichnus navesi, Estância Laguna Manantíales. D-F-G: Delatorrichnus goyenechei, Estância Laguna Manantiales.: E: Prosauropod or chirotherian hand-foot set; Las Higueras. I: (?) Lepidosaurian footprint; Rfo Los Tarros. H-K-M: Probable chirotherian hands; Rio Los Tarros. L: Dinosauroid footprint (Thecodontia or Coelurosauria); Rio Los Tarros. O-Q-R: Chirotherian footprints; Rio Los Tarros. P-T: Shimmelia chirotheroides, LosMenucos. S: Unceriosin footprint, Rio Los Tarros. U: Chirotherium higuerense; Las Higueras. A-B-C-D-F-G-J-N: Jurassic (Oxfordian). Other figures: Triassic. A-G-N-P-T: Museo de La Plata. B-C-D-E-H-I-J-K-L-M-O-Q-R-S: Fundación Miguel Lillo, San Miguel de Tucumán. F: Museo Argentino de Ciências Naturales, Buenos Aires. U: Museo de Cuyo, Mendoza. A: MLP s/n room VII, cupboard 4, drawer 37. B: LPV 3701/2 - C: LPV 3700. D: LPV 3690/1. E: LPV 2735. F: MACN 18615. G: MLP 65-X-31-11. H: LPV 3439.1: LPV 3445. J: LPV 3677/2-3. K: LPV 3449. L: LPV 3446. M: LPV 3438. N: MLP 65-XI-12-1/2. O: LPV 3452. P: MLP 60-XI-31-1. Q: LPV 3448. R: LPV 3441. S: LPV 3440. T: MLP $60-X I-31-\quad 2 . \quad$ P: Prancha I - Pegadas arcossaurianas da Argentina.

A-B-C-G-N: Wildesichnus navesi, Estância Laguna Manantiales. D-F-G: Delatorrichnus goyenechei, Estância Laguna Manantíales. E: Par mão-pé de prosaurópodo ou quirotério, Lãs Higueras. I: Pegada (?) lepidosauriana, Rfo Los Tarros. H-K-M: Mãos provavelmente quiroterianas, Rio Los Tarros. L: Pegada dinossauróide (Thecodontía ou Coelurosauria), Rfo Los Tarros. O-Q-R: Pegadas quirotenanas, Rio Los Tarros. P-T: Shimmelia chirotheroides, Los Menucos. S: Pegadas de classificação incerta, Rfo Los Tarros. U: Chirotherium higuerense, Las Higueras. A-B-C-D-F-G-J-N: Jurássico (Oxfordiano). Outras fíguras: Triássico. A-G-N-P-T: Museo de La Plata. B-C-D-E-H-I-J-K-L-M-O-Q-R-S: Fundación Miguel Lillo, San Miguel de Tucumán. F: Museo Argentino de Ciências Naturales, Buenos Aires. U: Museo de Cuyo, Mendoza. A: MLP s/n sala VII, armário 4, gaveta 37. B: LPV 3701/2. C: LPV 3700. D: LPV 3690/1. E: LPV 2735. F: MACN 18615. G: MLP 65-X-31-11. H: LPV 3439. I: LPV 3445. J: LPV 3677/2-3. K: LPV 3449. L: LPV 3446. M: LPV 3438. N: MLP 65-XI-12-1/2. O: LPV 3452. P: MLP 60-XI-31-1. Q: LPV 3448. R: LPV 3441. S: LPV 3440. T: MLP 60-XI-31-2. U: s/n 


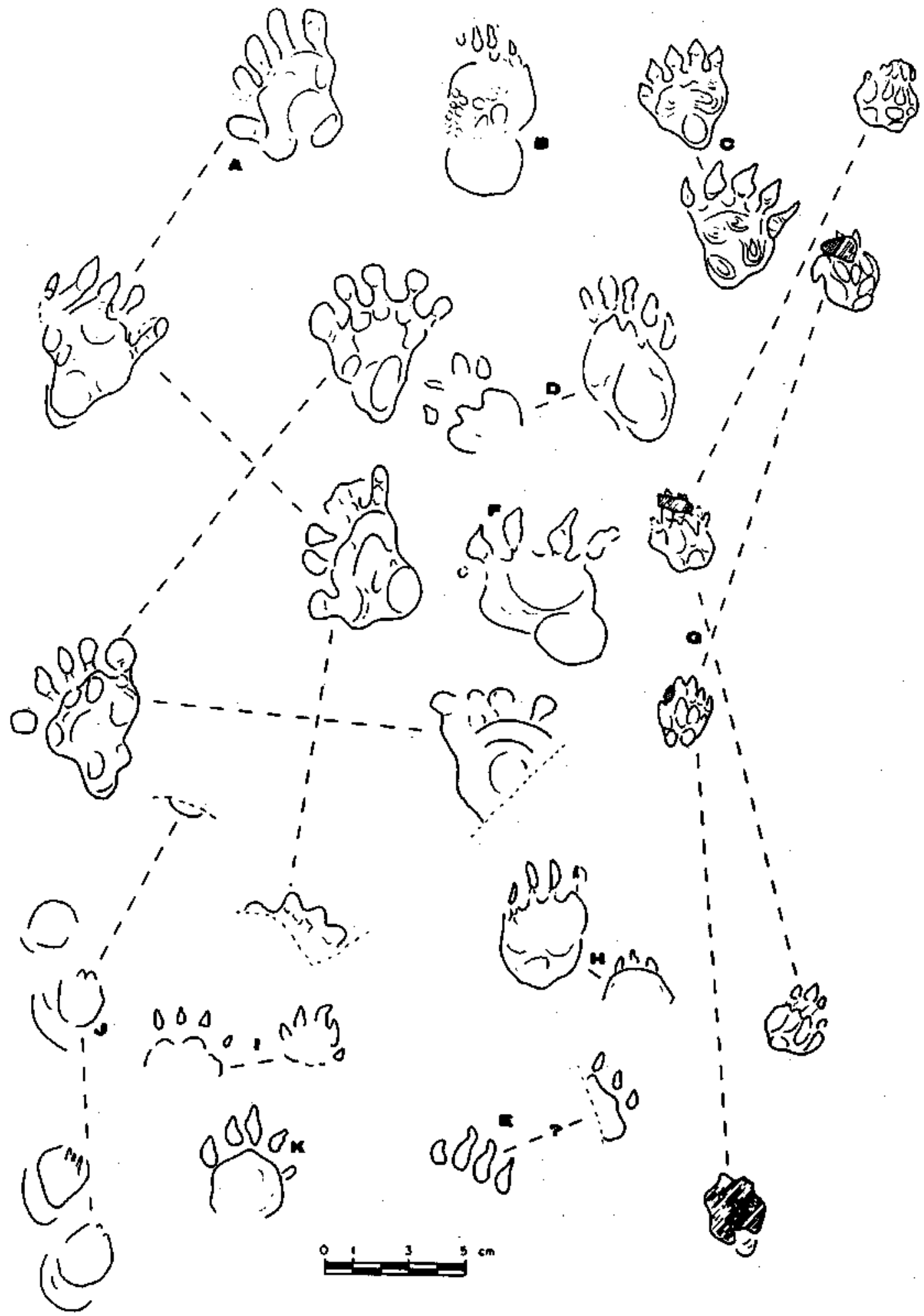

Plate II - Therapsid tracks from Triassic of Argentina.

A: Gallegosichnus garridoi, os Menucos. B-D-E-F-H-I-J-K: Therapsid footprints (description in text), Las Higueras. C: Calibarichnus ayestarani, Los Menucos. G: Palaciosichnus zettii, Los Menucos. A-C-G. Museo de La Plata. B-D-E-F-H-I-J-K-: Fundacion Miguel Lillo. A: MLP 60-XI-31-7. B: LPV 2730. C: MLP 60-XI-31-4. D: LPV 2738. E: LPV 2740/b. F: LPV 2741. G: MLP 60-XI-31 -6. H: LPV 2737/a. I: LPV 2737/b-c. J: LPV 3520. K: LPV 2740/a

Prancha TI - Pistas de terápsides do Triássico da Argentina.

A: Gatteosichnus garridoi, Los Menucos. B-D-E-F-H-I-J-K: Pegadas de terápsides (descrição no texto), Los Higueras. C: Calibarichnus ayestarani, Los Menucos. G: Palaciosichnus zettii, Los Menucos. A-C-G: Museo de La Plata. B-D-E-F-H-I-J-K: Fundacidn Miguel Lillo. A: MLP 60-XI-31-7. B: LPV 2730. C: MLP 60-XI-31-4. D: LPV 2738. E: LPV 2740/b. F: LPV 2741. G: MLP 60-XI-31-6. H: LPV 2737/a. I: LPV 2737/b-c. J: LPV 


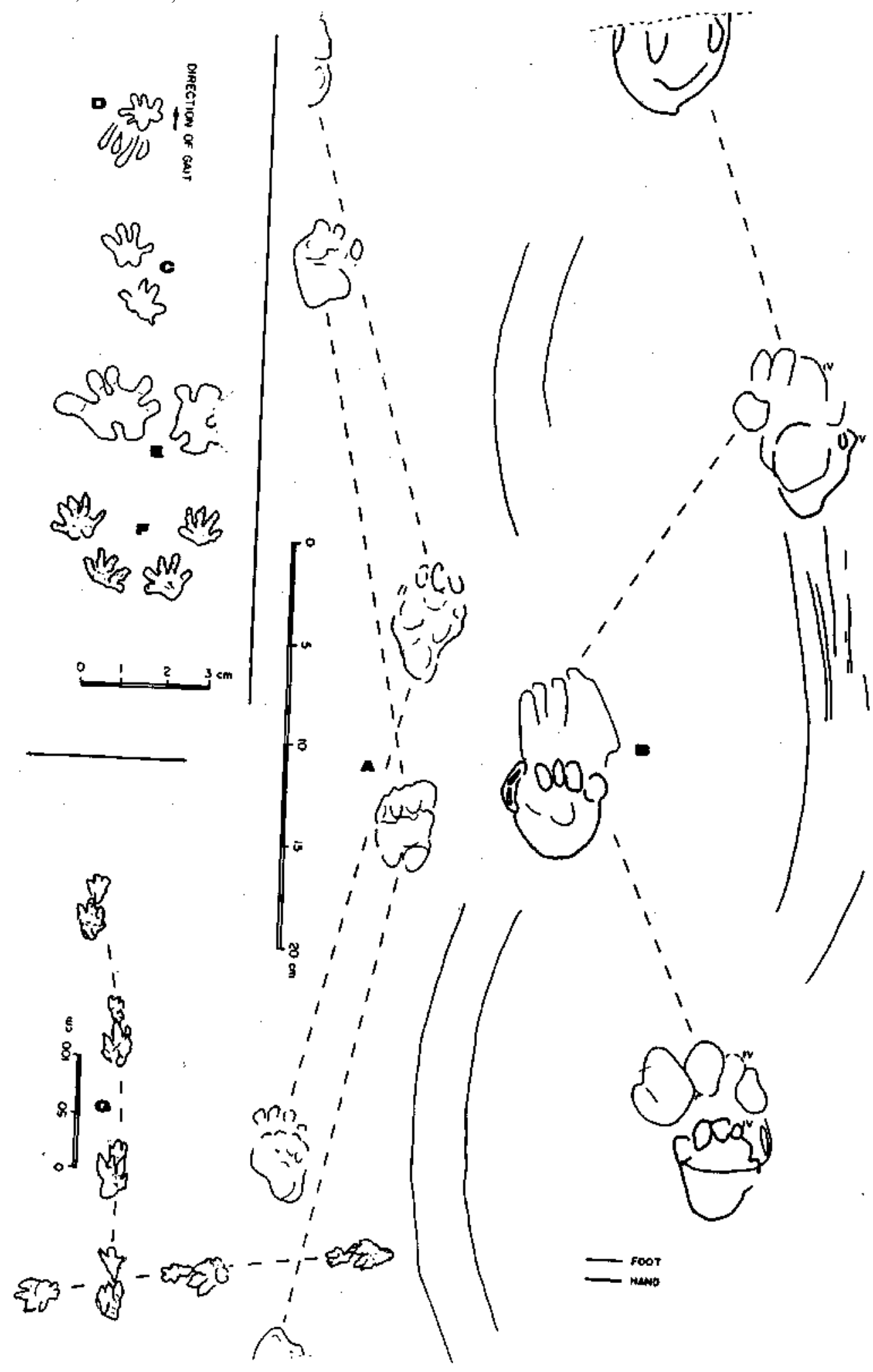

Plate III - Miscellaneous footprints from Argentina.

A: Trackway probably attributable to cynodonts, Los Menucos. B: Rogerbaletichnus aquilerai, note the drag of the feet, probably attributable to small Anomodontia, Los Menucos. C-F: Ameghinichnus patagonicus, Estância Laguna Manantiales. C: hand-foot set, walking gait; D: isolated footprint with digit drags; E: "gigantic" form; F: quadripedal set, gallop. G: Rigalites ischigualastianus, two trackways; Quebrada Los Rastros. All figures: Upper Triassic. A-C: Museo Argentino de Ciências Naturales. B-D-E-F: Museo de La Plata. A: MACN 18198.B: MLP 60-XI-31-5. C. MACN 18619. D: MLP room VII, cupboard 4, drawer 38. E: $\quad M L P \quad 60-X-31-13 . \quad$ F: $\quad M L P \quad 60-X-31-14 A$. G: $s / n$ (7in situ) Prancha III- Miscelanea de pegadas da Argentina.

A: Pista provavelmente atribuível a cinodontes, Los Menucos. B: Rogerbaletichnus aquilerai, observar o arraste dos pés, pista provavelmente atribuível a um pequeno Anomodontia; Los Menucos. C-F: Ameghinichnus patagonicus, Estância Laguna Manantiales. C: par mão-pé, andar caminhado; D: pegada isolada com arranhões; E: forma "gigante"; F: conjunto quadripedal de galope. G: Rigalites Ischnigualastianus, duas pistas; Quebrada Los Rastros. Todas as figuras: Triâssico Superior. A-C: Museo Argentino de Ciências Naturales. B-D-E-F: Museo de La'Plata. A: MACN 18198. B: MLP 60-XT-31-5. C: MACN 18619. D: MLP sala VII, armário 4, gaveta 38. E: MLP 60-X-31-13. F: MLP 60-X-31-14A. G: s/N (?in situ) 
were visited. Here, howevef, the rocks are finer grained and gray color (gray-green closer to the upper surface of the layers). While the material of "La Nueva"Quarry seems alluvial, that of "Cantera Tscherig" seem to represent deposite laid down in small lakes or lagoons on a fluvial floodplain. Footprints in the latter are abundant and usually of good to excellent quality. The following examples were found:

A. A trackway of Gallegosichnus garridoi Casamiquela 1964 and five trackways of $\mathrm{cf}<$ Gallegosichnus garridoi (PL VIII).

B. Three trackways of a probaly new theromorphoid form, that will be illustrated when the slab MACN 18198 of the Argentinean Museum is described (PL III.A; VLB).

C. Three trackways, one of which was in situ with more than 20 footprints, of the form illustrated but not named in Casamiquela (1964). These trackways were made by a small quadruped animal, and present the following characteristics: stride is about $28 \mathrm{~cm}$; oblique pace is about $16 \mathrm{~cm}$; trackway width is $16 \mathrm{~cm}-18 \mathrm{~cm}$; pace angulation is about $125^{\circ}$. The footprints are small round or elliptical and in sets, each presenting an axis forming an angle with the midline of $21^{\circ}$ to $33^{\circ}$. Neither Casamiquela nor the authors could observe morphological details; hence it is impossible to detemine the direction of the gait, or whether there is an overstep, and to distinguish hands and feet. From the dimensions and general pattern, these trackways can be defined as theromorphoid or mammaloid.

D. Two examples of a small mammaloid trackway with a lateral marginal overlap, reminiscent of forms from Botucatu Formation, in the State of São Paulo, Brazil (PL VLB).

E. At least ten other unclassifiable theromorphoid trackways. It was not possible to collect this material which consists of about 24 trackways. These finds were registered at the Paleontology Department of the Argentinean Museum of Buenos Aires.

The ichnofauna of Los Menucos listed above confirms the diagnosis of Casamiquela $(1964,1975 a)$ : it is a local, endemic almost exclusively therapsidian ichnofauna containing at least eight or ten forms, all of which are small- or medium-sized. The presence of primitive mammals can not be excluded. The commonest form is Gallegosichnus garridoi. The abundance of specimens and the possibility of discovering additional forms bespeak the importance of doing systematic and statistical studies at the site.

The Museum of Ingeniero Jacobacci (Province of Rio Negro). The museum of Natural Science, Archeology, Ethnology and History, was organized by R.M.Casamiquela, and besides some small slabs of little importance with dinosaur and early mammal footprints from the Estância Laguna Manantiales (Province of Santa Cruz), presents five excellent slabs from Los Menucos, but collected by Casamiquela from the sidewalks of the city of San Carlos de Bariloche, in the low Andes, around $200 \mathrm{~km}$ west of Los Menucos. The unpublished material includes:

A. A slab* about $45 \mathrm{~cm} \times 36 \mathrm{~cm}$ with a Galleogosichnus garridoi trackway with three hand-foot sets; one set of another individual of the same species; a set of an individual of larger dimensions, maybe of the same species imprinted when the mud was still soft (PL VIII.A).

B. A slab of $30 \mathrm{~cm}$ X $50 \mathrm{~cm}$ with an excellent trackway consisting of two sets of footprints of Gallegosichnus garridoi (PL VIII.C).

C. A trackway of Rogerbaletichnus aguilerai Casamiquela 1964 with five sets which the hands and feet are in anteroposterior contact but not in overlap as in the holotype (see below). Also in this case, the smaller autopodium is found behind the larger autopodium; it seems that the larger is the foot, and this oversteps the hand. The dragmarks, probably left by the foot, consist in this case, of four or five parallel lines formed by the dragging of five nails, or better, of five small hoofs (Pis. III.B and VII.A-B).

D. A trackway of five sets, without morphological details, of the group described above in item C) of the previous section.

Miguel Lillo Fundation (San Miguel de Tucumán) This institution, situated in the city of San Miguel de Tucumán, Northwest Argentina, has one of the two largest ichnological collections in that country. The following tetrapod ichnofossils are found in the collection:

A. Late Triassic ichnofauna of the headwaters of the Rio Los Tarros-Sur Pagancillo, La Rioja. It includes 15 small, reddish slabs numbered LPV (Laboratory of Vertebrate Paleontology) 3438 to LPV 3452, (Pis. I.H-I,K-M, O and Q-S), with complete or incomplete, almost exclusively chirotheroid footprints. Some of them, as a second, less probable hypothesis, could belong to small Prosauropoda. LPV 3441 (incomplete foot; Pis. I.R and V.F), 3448 (complete foot; Pis. I.Q and V.D) and 3452 (complete set; Pis. I.O and V.E) are exceptionally well preserved. Three of the four indeterminated footprints (LPV 3439, 3445 and 3447) seem to belong to quadrupedal forms, LPV 3445 is a short lacertoid footprint PL I.H-I).

B. Ichnofauna of the Estância Laguna Manantiales (Province of Santa Cruz) which includes:

1. 19 slabs of gray-green tuff with trackways of, almost always excellent quality, Ameghinichnus patagonicus Casamiquela 1964 sometimes accompanied by trails of coleopters. LPV 2743 shows a set of hands and feet that present crescents of tuffaceous sand pushed back by the feet of the animal as it climbed a dune as also observed in the eolian Botucatu Sandstones in the State of São Paulo, Brazil. In general, the sediments of Laguna Manantiales seem to have been wet and plastic when the footprints were made.

2. Three quadrupedal trails of Delatorrichnus goyenechei Casamiquela 1964 (PL I.D).

3. Four footprints of three different individuals of Wildeichnus navesi Casamiquela 1964. The material comes from the Chon Aike Formation, radiometrically dated at 160 Ma. Late Jurassic according to Urien (1981) (Pis. I.B-C and V.G).

C. Ichnofauna of Las Higueras (Province of Mendonza). The material consists of nine small slabs of fine sandstones to micaceous siltstone of a brown to a deep red color, coming from the Higuerense Formation correlatable with the Los Rastros Formation of Middle-Late Triassic age (museum numbers between LPV 2730 to 2741 and 3520) (PL II). Almost all of them present isolated footprints of the theromorphoid type in sets or very short trackways. Particularly noteworthy are:

1. The set of hands and feet (LPV 2738), very much like Dicynodontipus Lilienstern 1944 attributed to cynodonts.

2. LPV 3520 bears four footprints (of a total of five) accompained by the characteristic sand-crescent of the dune environment.

3. LPV 2730, a left footprint close to Dicynodontipus (Pis. II.B and VI.D). Very clearly preserved in this footprints are the impressions of the dermal plates, which are oval and bigger in the central part of the plant, round and smaller, ten in all, around the lateral margin. This arrangement corresponds to what is observed on the autopodia of some modern reptiles. The presence of dermal plates on a footprint, of a type generally attributed to cynodonts or bauriamorphs, contrasts with a footprint covered by hairs and/or bristles published by Ellemberger (1976), also attributed tentatively to cynodonts.

4. LPV 2741 is a theromorphoid footprint with fingers having relatively long nails (PL II.F).

5. LPV 2735 (Pis. IE and IV.E), a slab much larger than the others, presents an incomplete hand-foot set of an 


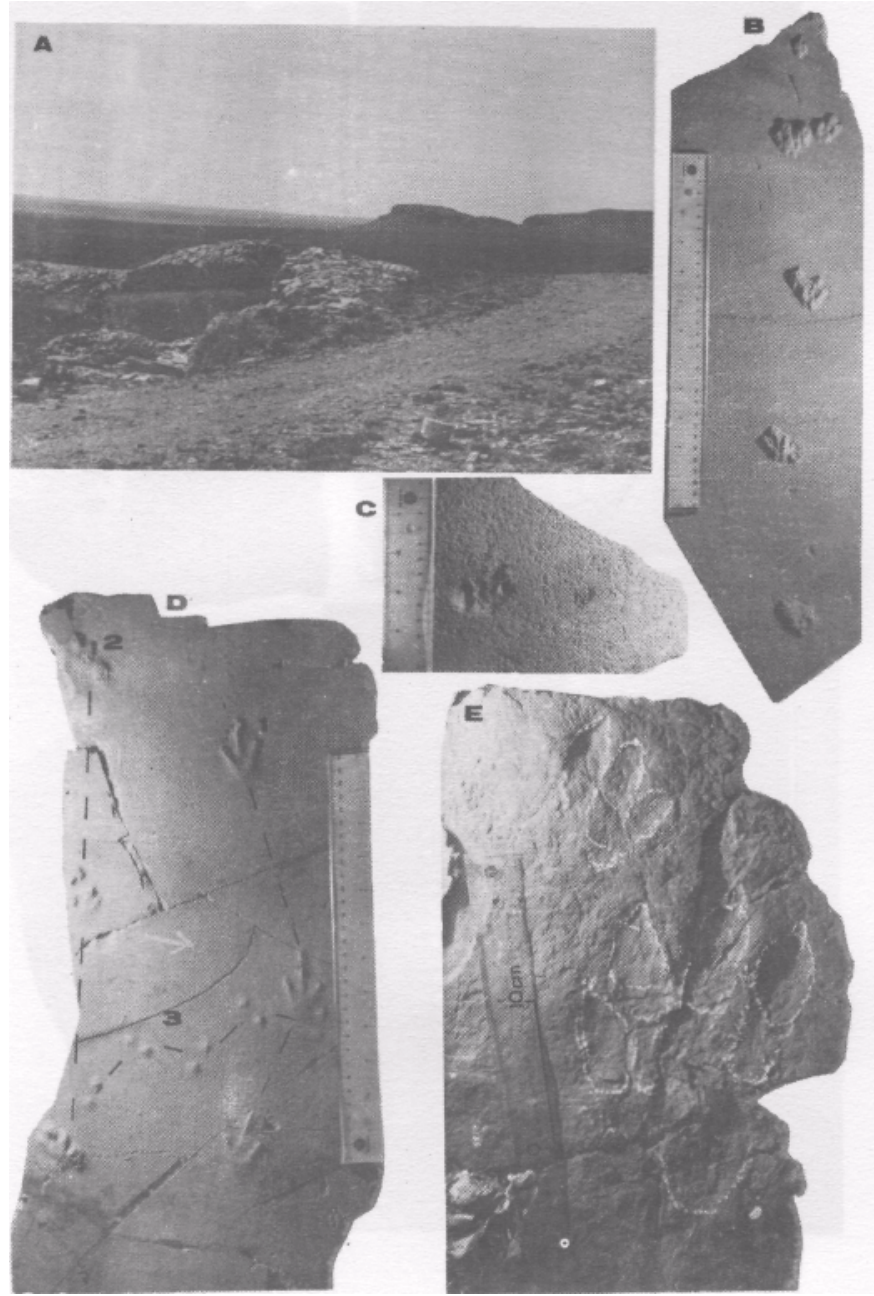

Plate TV - Footprints from Argentina.

A: "Cantera Nueva" (New Quarry), in Norian-Rhaetian tuffaceos sandstone, about $30 \mathrm{~km}$ west of Los imenucos (Rio Negro). At the backround, the Patagonian Plateau. B: Quadrupedal trackway of Delatorrichnus goyenechei. C: Delatorrichnus goyenechei. D. Associated trackways of: 1 Wildesichnus navesi; 2 - Delatorrichnus goyenechei; 3 Ameghinichnus patagonicus. E: Hand-foot set attributed to archosaurians, perhaps Prosauropoda ofChirotherium. B-D: Museo de La Plata. C: Museo Argentino de Ciências Naturales. E: Fundación Miguel Lillo. C: MACN 18615. D: MLP 65-XI-12-1/2. E: LPV 2735. Graphic scale in centimetres

Prancha IV - Pegadas da Argentina.

A: "Cantera Nueva" (Pedreira Nova), em arenitos tufáceos do Noriano-Retiano, cerca de $30 \mathrm{~km}$ oeste de Los Menucos (Rio Negro). Ao fundo o Platô da Patagônia. B: Pista quadrúpede de Delatorrichnus goyenechei. C: Delatorrichnus goyenechei. D: Pistas associadas de: I Wildesichnus navesi; 2 - Delatorrichnus goyenechei; 3 - Ameghinichnus patagonicus. E: Par mão-pé atribuído a arcossauros, talvez Prosauropoda ou Chirotheríuni. B-D: Museo de La Plata. C: Museo Argentino de Ciências Naturales. E: Fundación Miguel Lillo. C: MACN 18615. D: MLP 65-XI-12-1/2. E: LPV 2735. Escala gráfica em centímetros

archosaurian. The hand has four fingers; the foot appears to be tetradactyl, but the slab is incomplete exactly at the point where a fifth finger in abduction may have existed, so that doubts still remain as to its classification. It could be of prosauropod or chirotherian origin. In either case, the

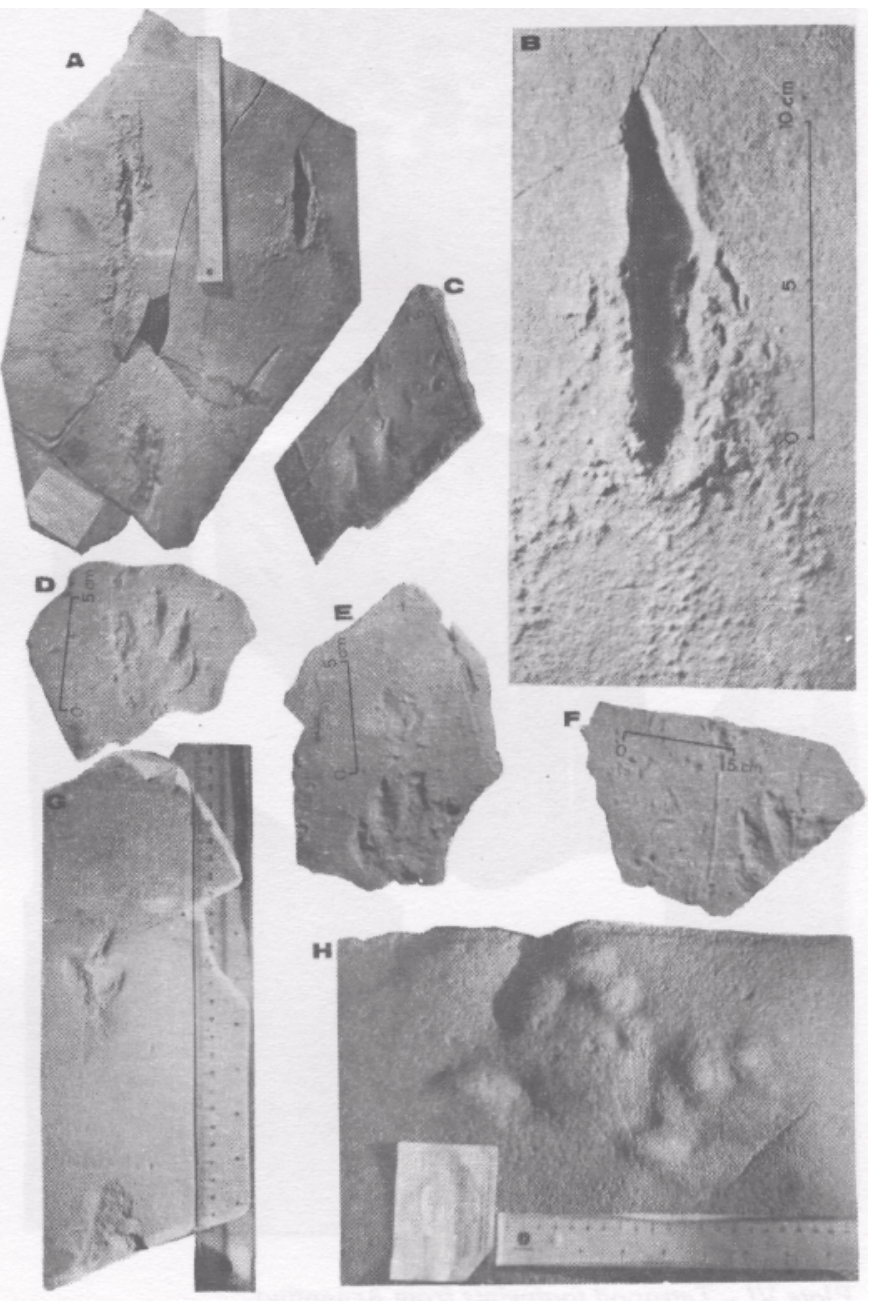

Plate $V$-Archosaurian footprints from Argentina.

A-B: Footprint of Sarmientichnus scagliai, attributed to a medium sized coelurosaur. C: Uncertain footprint C?Chirotherium). D-E-F: Chirotherian footprints. G: Wildesichnus navesi. H: Holotypes of Shimmelia chirotheroides. A-B-H: Museo de La Plata. C-D-E-F-G: Fundación Miguel Lillo. C: $L P V$ 3440. D: $L P V$ 3448. E: $L P V$ 3452. F: $L P V$ 3441. G: $L P V$ 3700. H: $M L P$ 60-XI-31-1. Graphic scale in centimetres

Prancha V - Pegadas arcossaurianas da Argentina.

A-B: Pegada de Sarmientichnus scagliai, atribuída a um celurossauro de médias dimensões. C: Pegada de classificação incerta (IChirotherium). D-E-F: Pegadas quiroterianas. G: Wildesichnus navesi. H: Holótipo de Shimmelia chirotheroides. A-B-H: Museo de La Plata. C-D-E-F-G: Fundación Miguel Lillo. C: LPV 3440. D: LPV 3448. E: LPV 3452. F: LPV 3441. G: LPV 3700. H: MLP 60-XÍ-31-1. Escala gráfica em centímetros

therapsid-archosaurian association is interesting. Same outcrop gave the Chirotherium hiquerense Rusconi 1952 (=Ch. bartill Kaup 1835) (PI. I.U).

D. Trackways of Rigalites of the "Quebrada Los Rastros" (Province of San Juan; Los Rastros Formation) (PI. III.G). In the gallery of the museum of the Lillo Fundation, a short trackway of the Rigalites Heune 1931 b is on display which shows a hand-foot set and the sucessive foot.

Argentinean Museum of Natural Science (Buenos Aires) The collection consists of the following items: A. Ichnofauna of the Estância Laguna Manantiales. Nine 


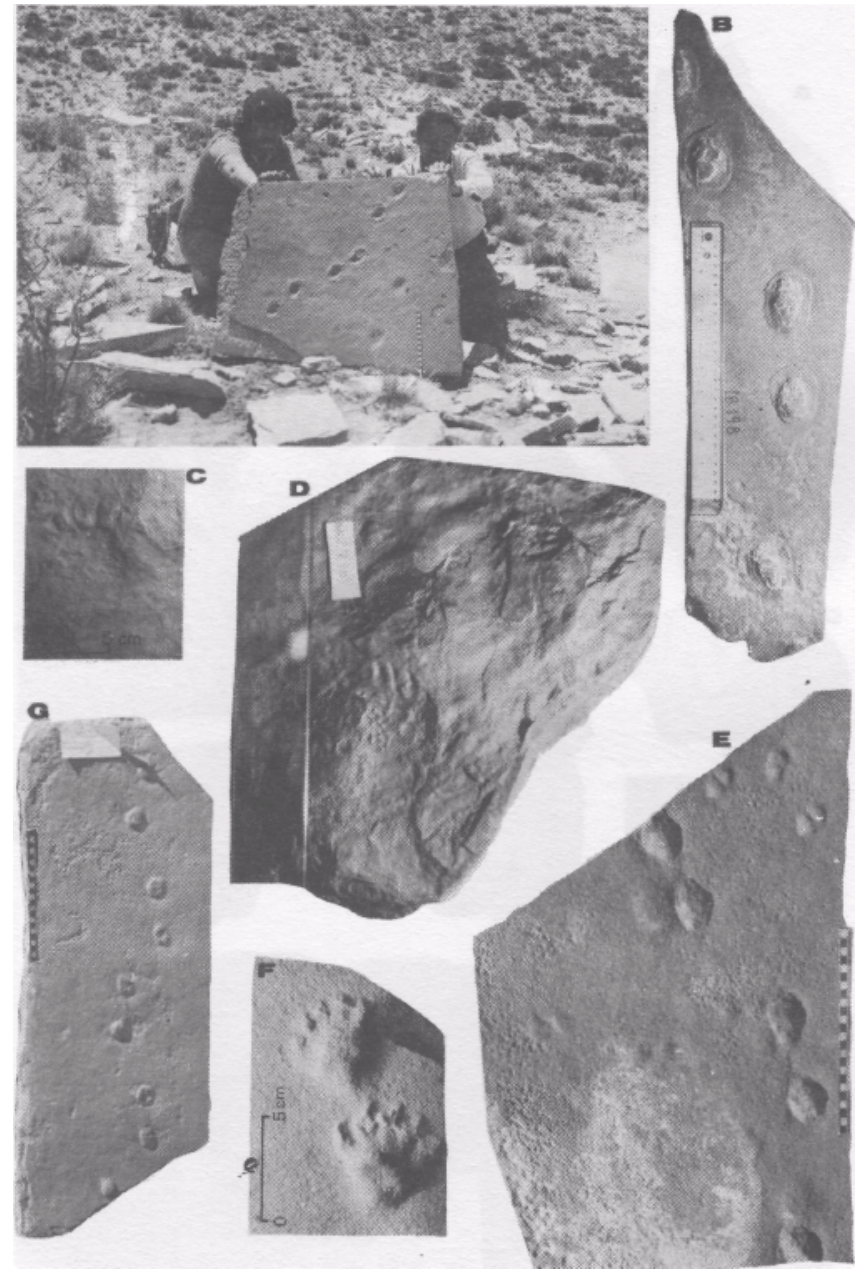

Plate VI- Tetrapod footprints from Argentina. A: Quarry "La Vieja" (Los Menucos), trackways of a new form attributed to cynodonts. B: Trackway attributed to cynodonts. C: Single footprint ofcynodont. Note the lenght of the toes and the claws. D. Footprint attributed to cynodonts, which presents dermic plates of two different sizes; Higuerense Formation, Middle-Late Triassic. E: Theromorphoid trackway probably attributed to unnamed new cynodont. Observe a mammaloid trackway with a marginal overlap, which looks like trackways ofBotucatu Formation and also like Ameghinichnus patagonicus in its general pattern; Los Menucos - Tscherig Quarry. F: Holotype of Calibarichnus ayesterani. G: A mammaloid trackway with a very characteristic pattern but lacking morphological details; Los Menucos - Tscherig quarry. B: Museo Argentino de Ciências Naturales. C-D: Fundación Miguel Lillo. F: Museo de La Plata. B: MACN 75795. C: LPV 2741. D: LPV 2730. F: MLP 60-XI-31-4. Graphic scale in centimetres Prancha VI - Pegadas de tetrápodes da Argentina. A: Pedreira "La Vieja" (Los Menucos), pistas de uma nova forma atribuída a cinodontes. B: Pista atribuída a cinodontes. C: Pegada avulsa de cinodonte. Observar o comprimento dos dedos e garras. D: Pegada atribuída a cinodontes, que apresenta placas dérmicas de dois tamanhos diferentes; Formação Higuerense, Triássico Médio-Superior. E: Pista teromorfóide provavelmente atribuível a uma nova forma de cinodonte. Observar uma pista mamalóide com sobreposição marginal, semelhantes as pistas encontradas na Formação Botucatu e também semelhante ao padrão geral do Ameghinichnus patagonicus; Los Menucos - Pedreira Tscherig. F: Holótipo de Calibarichnus ayestarani. G: Pista mamalóide de padrão muito característico mas sem detalhes morfológicos; Los Menucos - Pedreira Tscherig. B: Museo Argentino de Ciências Naturales. C-D: Fundación Miguel Lillo. F: Museo La Plata. B: MACN 18198. C: LPV 2741. D: LPV 2730.F: MLP 60-XI-31-4. Escala gráfica em centímetros

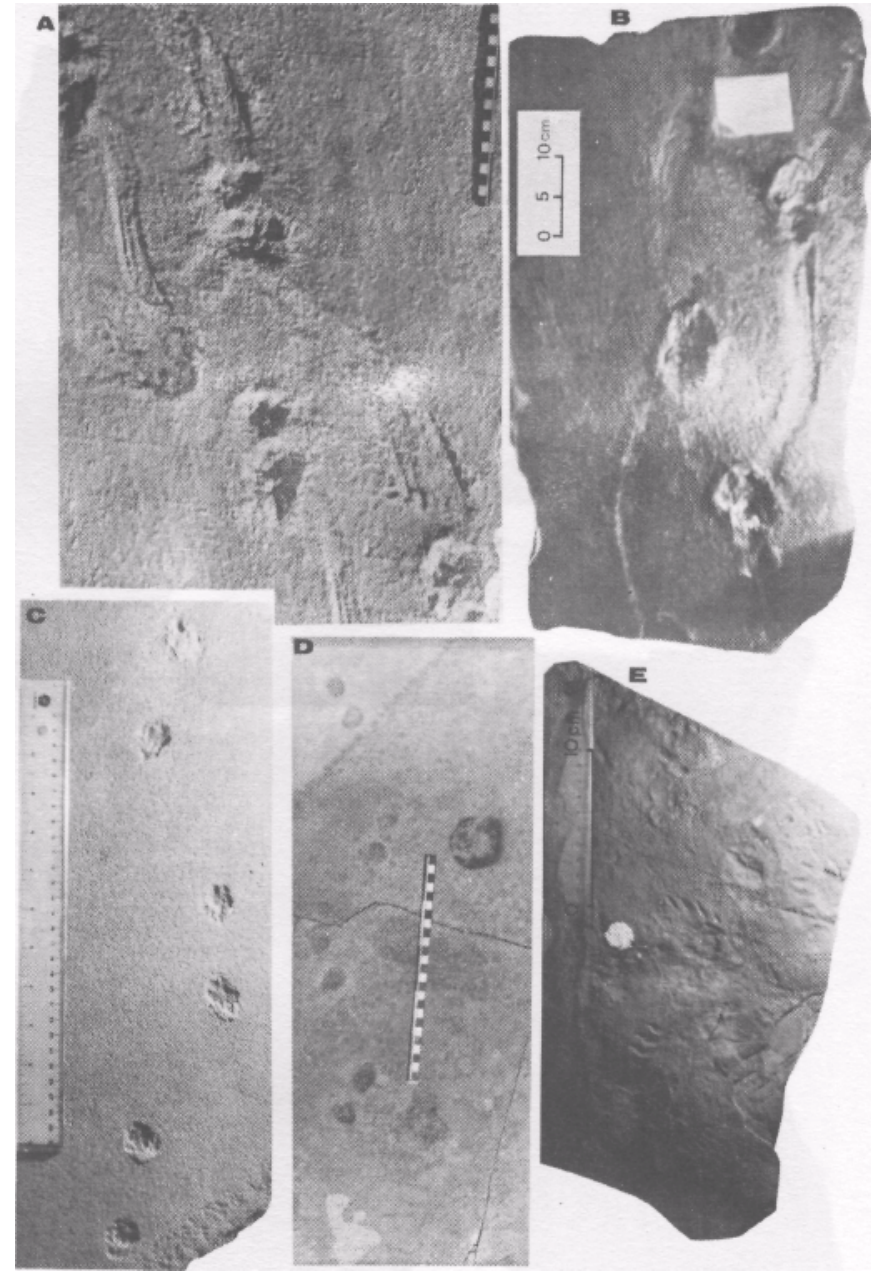

Plate VII - Tetrapod trackways from Argentina. A-B: Trackways of Rogerbaletichuns aguilerai. Note the scratches left by the feet dragging across the ground, which seem to be constant characteristic of this form. Unlike in the holotype, the feet overlap the hands; Los Menucos - Tscherig Quarry. C: Holotype of Palacioschnus zettii. D: A mammaloid trackway, form illustrated but not named in Casamiquela (1964); Los Menucos - Tscherig Quarry. E: Slab with several theromorphoid footprints; Rio Los Tarros. A-B-C: Museo de La Plata. E: Fundación Miguel Lillo. A-B: MLP 60-XI-31-5. C: MLP 60-XI-31-6. E: LPV 2740. Graphic scale in centimetres

Prancha VII - Pistas de tetrapódes da Argentina. A-B: Pistas de Rogerbaletichuns aguilerai. Observar a marca de arraste dos pés no chão, que parece ser uma característica constante desta espécie. Diferente do holótípo, o pé sobrepõe à mão; Los Menucos - Pedreira Tscherig. C: Holótipo de Palacioschnus zettii. D: Pista mamalóide, forma ilustrada, mas não descrita em Casamiquela (1964); Los Menucos - Pedreira Tscherig. E: Laje com várias pegadas teromorfóides; Rio Los Tarros. A-B-C: Museo de La Plata. E: Fundación Miguel Lillo. A-B: MLP 60-XI-31-5. C: MLP 60-XI-31-6. E: LPV 2740. Escala gráfica em centímetros

slabs with trackways of Ameghinichnus patagonicus numbered MACN (Museo Argentino de Ciências Naturales) 18616 a 18623 , and the slab MACN 18528 with a hand and foot set of a quadrupedal trackway of Delatorrichnus goyenechei. The foot is particularly well preserved: on the fourth toe are four pads, and a claw and a large distal pad are evident on the third toe (Pis. I,.F, III.C and IV.C). 


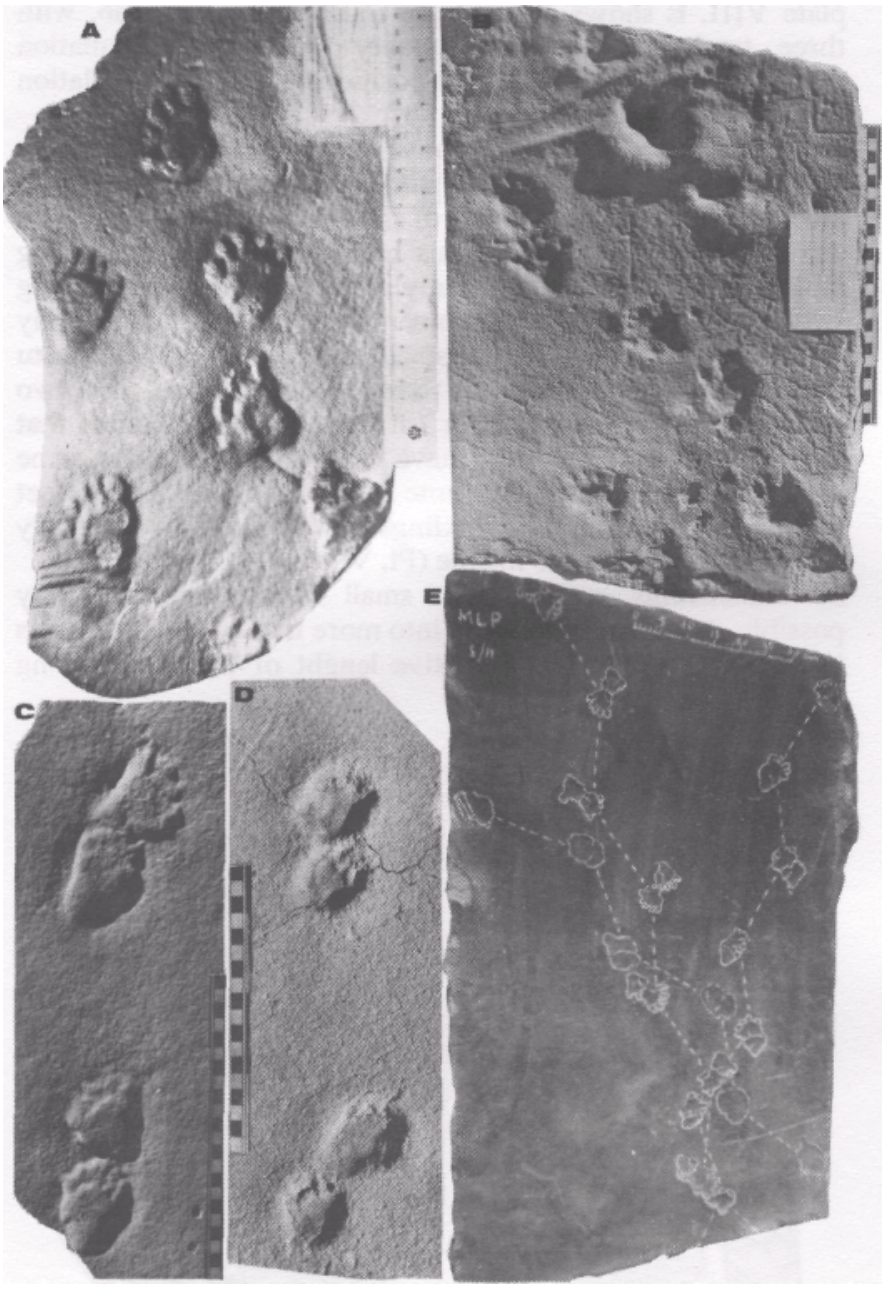

Plate VIII - Trackways of Gallegosichnus garridoi from Los Menucos, Argentina.

A: Holotype. B: Slab with trackways of three individuals. C: Two fine hand-foot sets. D: Trackway of Gallegosichnus type. Observe the overstep and the dimension of the hands in relation of the feet. E: Three trackways which show the variability of the position of the hands in relation to the feet. A-E: Museo de La Plata. A: MLP 60-XI-31-7. E: MLP s/n. Graphic scale in centimetres

Prancha VIII - Pistas de Gallegosichnus garridoi procedentes de Los Menucos, Argentina.

A: Holótípo. B: Laje com pistas de três indivíduos. C. Dois pares mãopé. D: Pista semelhante a de Gallegosichnus. Observar a ultrapassagem da mão pelo pé e as dimensões das mãos com relação ao pés. E: Três pistas que mostram a variabilidade da posição das mãos com relação aos pés. A-E: Museo de La Plata. A: MLP 60-XI-31-7. E: MLP s/n. Escala gráfica em centímetros

B. A slab of the Tscherig Quarry of Los Menucos, with a trackway (cast) of three incomplete sets not very well preserved (MACN 18198). It seems to be a different form from the others published in Casamiquela $(1964,1975 a)$ and it is relatively common in Los Menucos. The general pattern is typically theromorphoid, perhaps a long-legged and running cynodont. Morphological details are not clear (Pis. III.A and VLB).

La Plata Museum The famous La Plata Museum has the largest ichnological collection in Argentina and in Latin America as well, collected almost entirely by Dr. R. M.
Casamiquela in th 60's and early 70's.

A complete list of the material, which contains around 140 slabs with trackways or isolated footprints, will be given elsewhere. The most interesting pieces are commented here: A. Ichnofauna of Los Menucos. All the types of the forms published in Casamiquela (1964) and some unpublished pieces are kept here:

1. Shimmelia chirotheroides: both the holotype and the paratype are of poor quality and not well preserved, but they are without a doubt, chirotherian. Probably the genus should be mantained since the footprints present distinct characteristics, some of which are: the hand is in a backwards and medial position in relation to the foot; the hand is very large; the third toe is squeezed between the second and the fourth toes and is impressed only in correspondence of the ungual phalange. In relation to the description of Casamiquela (1964), the authors should add that the claws are very visible; and that the fifth toe does not seem to be falciform (Pis. I.P.T and V.H).

2. Calibarichnus ayestarani: the hand-foot set is very fine. The plates II.C and VI.F show in detail the ungual pads of the sole and palm.

3. Rogerbaletichnus aquilerai ( $R$. aquilerani in errore): to the description in Casamiquela (1964) the authors should add that

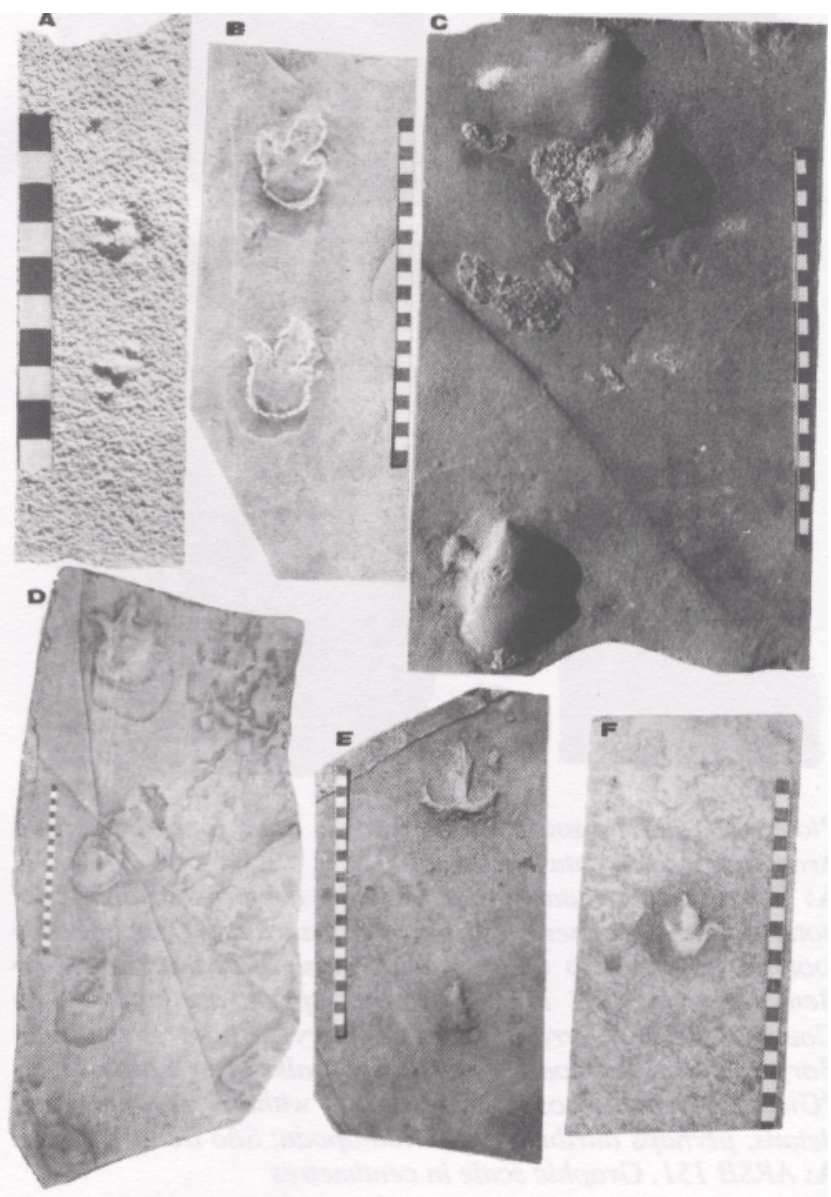

Plate IX - Dinosauroid tracks in sidewalks of Araraquara.

A: Mammaloid or dinosauroid tracks showing biped "ricochef gait. B-F: Dinosauroid tracks from sidewalks. Graphic scale in centimetres

Prancha IX -Pegadas dinossauro)dês nas calçadas de Araraquara.

A: Pista mamiferóide ou dinossauróide mostrando um andar do tipo "ricochete". B-F: Pegadas dinossauróides provenientes de calçadas. Escala gráfica em centímetros 
the toes are almost always very visible in the form of small subpolygonal hoofs and the fifth finger has the form of as sharp falciform nail. The constancy of these characteristic, and of the dragging walk, was mentioned above (Pis. III.A and VII.A-B).

4. Palaciosichnus zettii: it does not seem that the very particular form illustred in Casamiquela (1964) must be mantained for the toes. Probably, ignoring the cavities that depend on erosion, it is a very common trackway that looks like Dicynodontipus (Pis. II.G and VII.C).

5. Gallegosichnus garrido: the very good preservation of the morphological details can be seen in plates 11 and VÍT1. The

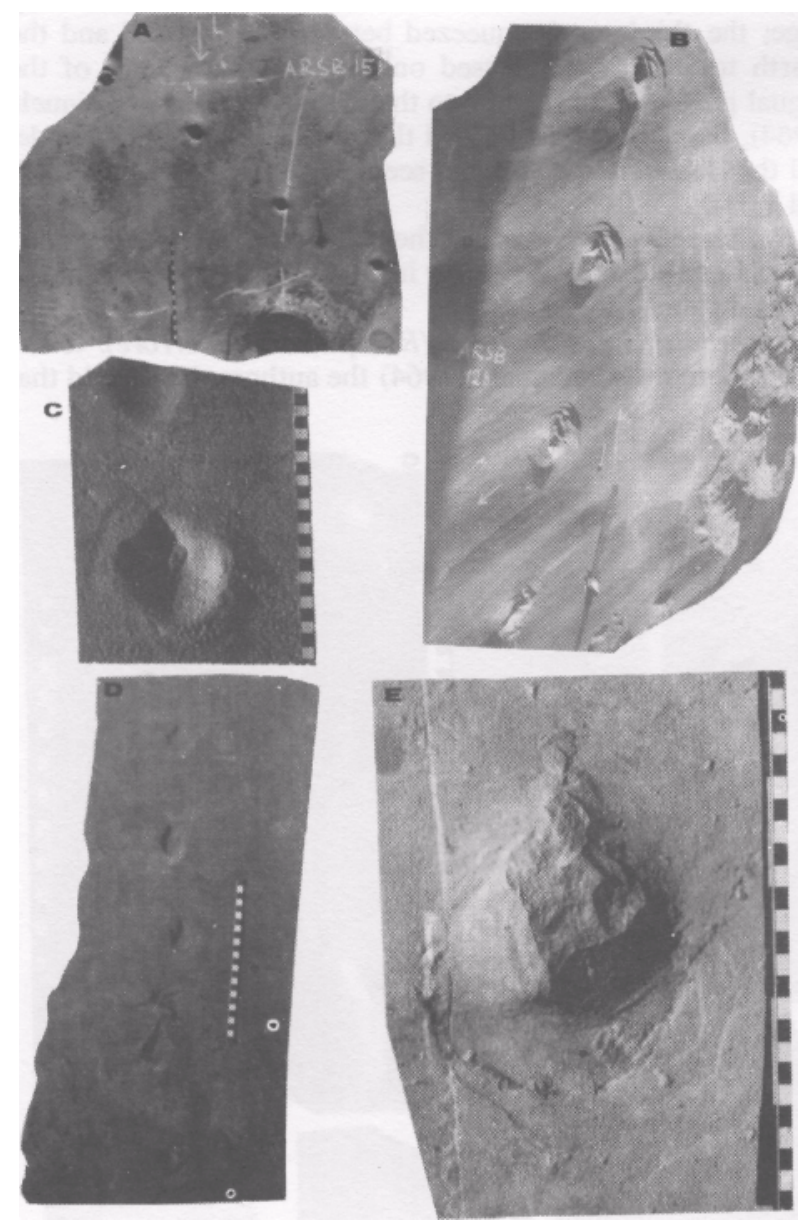

Plate X - Dinosauroid trackways and footprints from Araraquara. Botucatu Formation.

A: Trackway attributable to a small size coelurosaurian. At the bottom-right part there is a big dinossaurian (?Ornithopoda) footprint; São Bento Quarry. B: Dinosaurian trackway; São Bento Quarry. C: Dinosaurian footprint attributed to a Coelurosauria; Cerrito Novo Quarry. Photo by Guido Borgomanero. D: Coelurosauria, sidewalks of Araraquara. E: "Gianf bipedal dinosaurian footprint without morphological details, perhaps attributed to Omithopoda; São Bento Quarry. A: ARSB 151. Graphic scale in centimetres Prancha X - Pistas e pegadas dinossaurianas provenientes de Araraquara, Formação Botucatu.

A: Pista atribuível a um pequeno celurossauro. Em baixo à esquerda uma pegada de dinossuro relativamente grande (?Ornithopoda); Pedreira São Bento. B: Pista dinossauriana; Pedreira São Bento. C: Pegada dinossauriana atribuída a Coelurosauria; Pedreira Cerrito Novo. Foto de Guido Borgomanero. D: Coelurosauria, calçadas de Araraquara. E: Pegada "gigante" de dinossauro bípede sem detalhes morfológicos, talvez atribuível a Ornithopoda; Pedreira São Bento. A: ARSB 151. Escala gráfica em centímetros plate VIII. E shows a large, previously unfigured slab, with three trackways of good quality (without matriculation number). The variability of the position of the hand in relation to the foot should be noted.

B. Ichnofauna of the Estância Laguna Manatiales. This comprises the richest part of the collection, with about 100 pieces. The collection consists of the following items:

1. Sarmientichnus scagliai: this has an extremely interesting bipedal gait, usually monodactyl, but sometimes presenting two or three toes. This phenomenon of variability of dactyly is characteristic also of a small dinosaur from Botucatu Formation in the State of São Paulo, Brazil. The two formations are probably both Jurassic, and it is possible that the two trackmakers may have originated from the same group. The authors need to note that the Sarmientichnus feet constantly raised three sprinklings of wet sand: two laterally and a smaller one in the middle (PL V.A-B).

2. Wildeichnus navesi: this small dinosaurian trackway possibly should be subdivided into more than one ichnospecies because of the different relative lenght of the toes, among

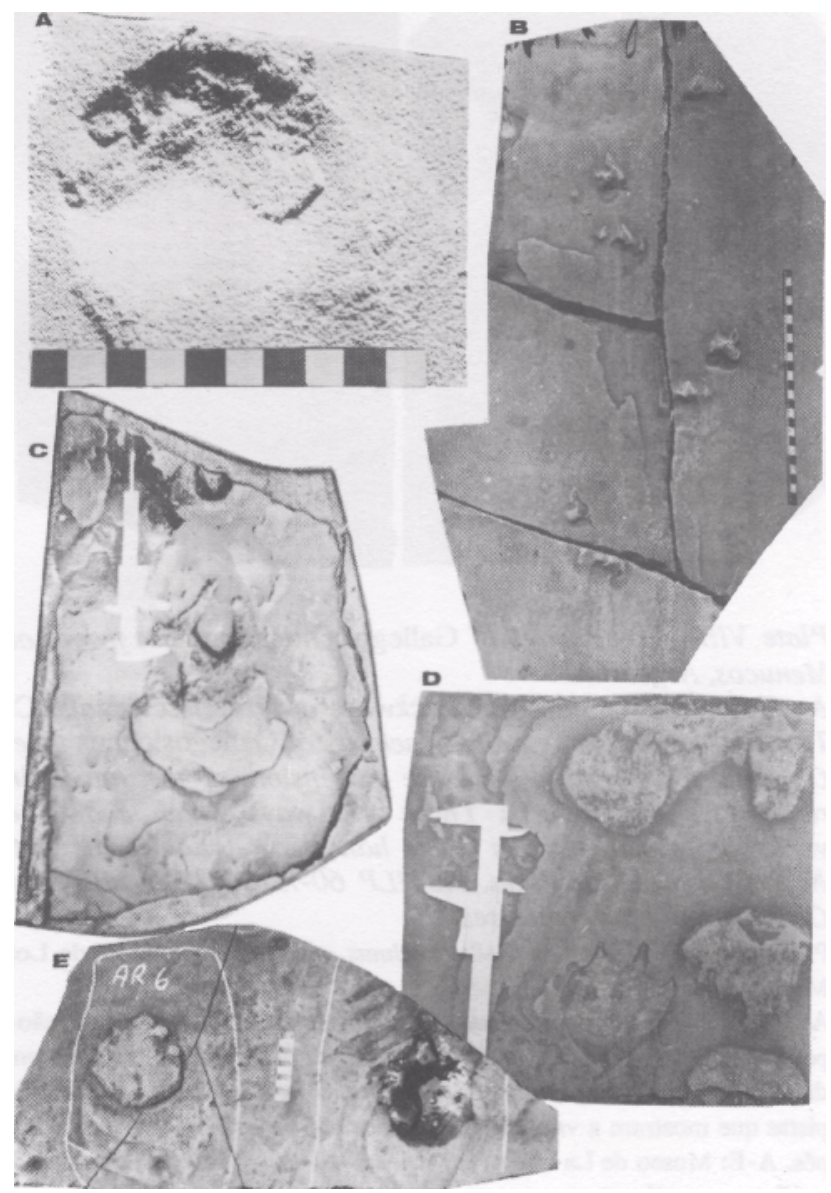

Plate XI - Theromorphoid footprints from Botucatu Formation. A: Theromorphoid footprint; São Bento Quarry. B: Flastone from sidewalks of São Carlos, attributed to a large tritylodont. C-E: Theromorphoid footprints form pavements of: $\boldsymbol{C}$ Rifaina; D - São Carlos; E - Araraquara. F: Mammaloid quadrupedal set. B-C-D-E-F: DNPM, Rio de Janeiro (repository). B: MNRJ 3903. Graphic scale in centimetres Prancha XI - Pegadas termorfdides da Formação Botucatu. A: Pegada teromorfóide: Pedreira São Bento. B: Laje das calçadas de São Carlos, atribuída a um grande tritilodonte. C-E: Pegadas teromorfóides das calçadas: C - Rifaina; D - São Carlos; E - Araraquara. A: $A R S B$ 104. Escala gráfica em centímetros. O paquímetro está aberto a $5 \mathrm{~cm}$ 
other details (Pis. I.A.G.N. and IV.D).

3. Delatorrichus goiyenechei: the hand is frequently bidactyl but sometimes, as in the holotype itself, a third toe is clearly visible. Some digital pads are also observed here, particulary on the fourth, but sometimes also on the third finger (PL IV. D).

4. Ameghinichnus patagonicus: the number and beauty of specimes are very impressive. Besides the commonest form, skillfully described and interpreted in Casamiquela (1964, 1975b), the authors should note some different forms; including a gigantic form (for examples: MLP - Museo de La Plata - 60-X-31-13; PL III.E); and some trackways in which the footprints, from the abducted position of the first and fifth toes, are a little reminiscent of some crocodiloid footprints (manus).

C. The collection also includes a series of large plaster cast of some hand-foot sets of Rigalites ischigualastianus Huene 1931 b that were probably made from moulds prepared with wet newspaper by Huene at Campo de Ischigualasto (Huene 1931b) (PL III.G).

D. Slabs with footprints from Germany in the collection include some beautiful slabs with Chiotherium footprints and two large slabs with Ichniotheriwn Pohlig 1885 footprints. This material was probably obtained through exchange.

BOTUCATU FORMATION ICHNOFAUNA (BRAZIL) Introduction The Botucatu Formation has a very extensive outcrop in South America, on both sides of Paraná Basin. From north to south, on its eastern side it crossess the Brazilian states of Minas Gerais, São Paulo to Rio Grande do Sul, extending also into Uruguay; on its western side, the Brazilian states of Goiás and Mato Grosso do Sul, extending southward into Paraguay and Northern Argentina. The calculated extent of this formation, according to Sanford \& Lange (1960), is about $1.300 .000 \mathrm{~km}^{2}$. Yet, depite this enormous outcrop, its date is not known with any precision. The reason for this is the environment: it represents a hot, dry continental interior, where conditions were never less than semi-arid and widely those of a desert. In these sediments body fossils of animals and plants do not occur, nor pollens. All that can be said with certainty (on their date), is that about 120-140 Ma ago, volcanic activity produced the flood basalts of the Serra Geral Formation that capped the Botucatu Sandstones over almost the whole area (Cordani \& Vandoros 1967). Whether there was a time interlude between the deposition of the sediments and the volcanic episode is uncertain. It's possible that the sediments inter finger with the basalts in places, but this has not yet been conclusively demonstrated.

Vertebrate footprints and invertebrate trails in the Botucatu Sandstone were first observed in 1913 by Brazilian mining engineer Joviano Pacheco, but were only much later reported in print by German vertebrate palaeontologist Friedrich von Huene (Huene 193la). They were noticed in the flagstones of a pavement in the town of São Carlos, about 40 $\mathrm{km}$ southeast of Araraquara (Fig. 1). So far as the authors can determine, the flagstones came from the Santa Águeda quarry in Ouro district, a quarry presentely inactive, near Araraquara.

One of the authors (G.L.) found the Ouro quarries initially in 1976. At that time four or five quarries were still being actively worked, the stone being used for making sidewalks and facing buildings; but a decline in demand has brought the progressive closure of most of these quarries and at present only the largest, São Bento, remains open. An account of the sedimentology, paleo-environment and palaeoichnology of this quarry was published in Leonardi (1980).

Between 1976 and the present, natural exposures, quarries and town pavements throughout the eastern outcrop of the Botucatu Formation, from Rio Grande do Sul to Minas

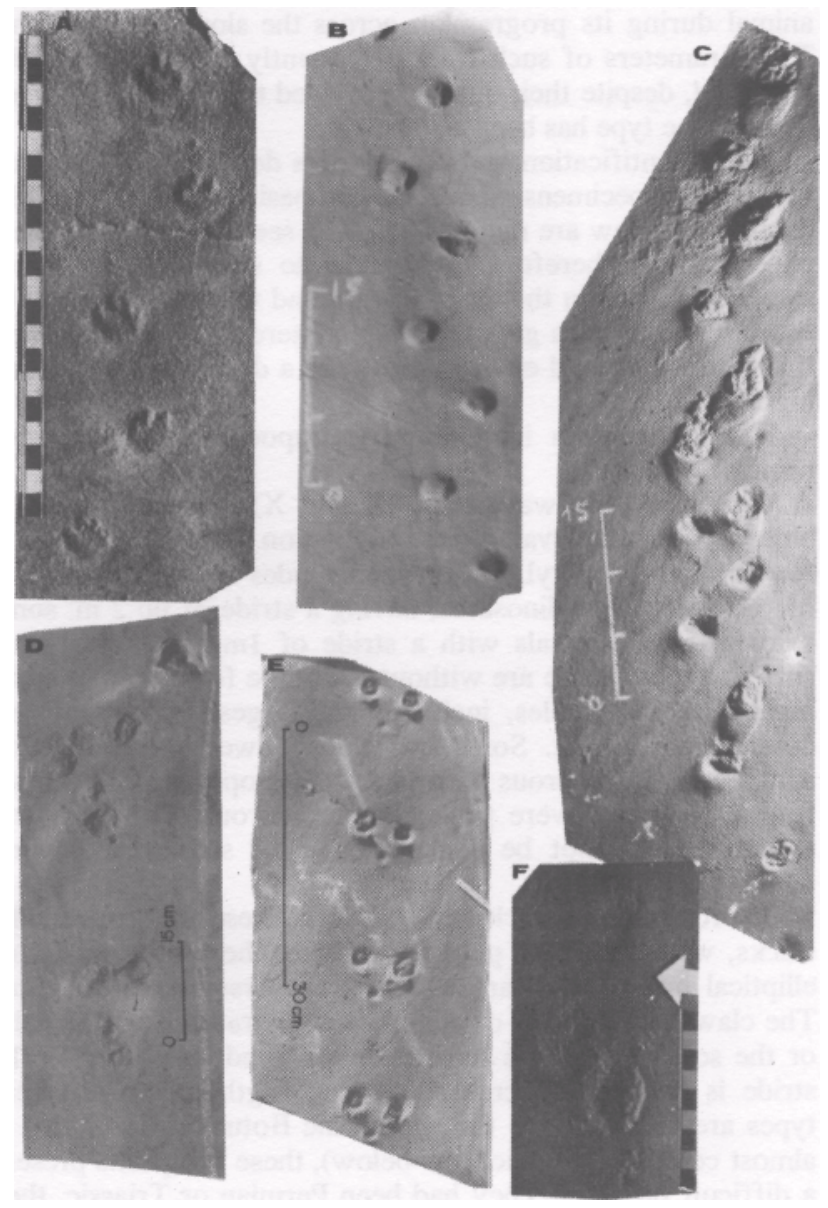

Plate XII - Mammaloid trackways from Botucatu Formation. A: Quadruped mammaloid trackway from the Araraquara sidewalks, this is very similar to Brasilichum sp., but the footprint is tetradactyL B-C: Paratype and holotype of Brasilichum elusivum. D-E: Trackways that show galloping gait. F: Mammaloid quadrupedal set. B-C-D-E-F: DNPM, Rio de Janeiro (repository). B: MNRJ 3903. C: MNRJ 3902. Graphic scale in centimetres

Prancha XII - Pistas mamalóides da Formação Botucatu. A: Pista quadrúpede mamalóide das calçadas de Araraquara, esta é muito similar à Brasilichum sp., mas a pegada é tetradatila. B-C: Parátipo e holótipo de Brasilichum elusivum. D-E: Pistas que mostram andar de galope. F: Conjunto quadripedal mamalóide. B-C-D-E-F: DNPM, Rio de Janeiro (repositório). B: MNRJ 3903. C: MNRJ 3902. Escala gráfica em centímetros

Gerais, were explored by one of the authors (G.L.), special attention being paid to those in the three northern states. The recovery of fossils was starting. Vertebrate footprints were found in four Brazilian states - from Sacramento (Minas Gerais); Araraquara, Brodósqui, Rifaina, Analândia and Botucatu (São Paulo); Jacarezinho (Paraná); Santa Cruz do Sul and Tramandai (Rio Grande do Sul) - a belt $2.500 \mathrm{~km}$ long (Leonardi 1977, 1980, 1981 Leonardi \& Godoi 1980, Leonardi \& Sarjeant 1986).

The Ichnofauna of Araraquara The vertebrate tracks

from the Ouro quarries and in the sidewalks of Araraquara are almost always of poor quality, the footprints being simply a rounded or elliptical cavity furnishing no morphological details. Characteristically this cavity is accompanied by a crescent sandstone ridge, always in the direction of the 
foreset dip, representing the sand displaced by the foot of the animal during its progression across the slopes of the dune. The parameters of such tracks frequently enable them to be classified, despite their quality, provided that a good specimen of the same type has been also found.

Firm identification and descriptions depend necessarily on the better specimens and it is on basis of these that the comments below are made. The fauna seems to be completely endemic and, therefore, quite new to science. This factor causes problems in the classification and interpretation of the footprints, but adds greatly to their interest. As noted earlier, this was a very arid environment, like a desert or semi-desert highland.

The Araraquara ichnofauna (tetrapods) comprises three principal groups:

A. Dinosaur trackways (Pis. IX and X). These are always bipedal, with an elevated pace angulation (up to $180^{\circ}$ ) and the foot is always tridatyl. This group includes two or three forms of relatively large dinosaurs, having a stride of up $2 \mathrm{~m}$; some medium-sized animals with a stride of $1 \mathrm{~m}-1.5 \mathrm{~m}$; and some smaller types. These are without doubt the footprints of agile, highly mobile reptiles, including the largest animals of this desert environment. Some had thin, clawed toes and were apparently carnivorous dinosaurs (Theropoda). The larger forms, however, were probably herbivorous (Ornithopoda), though this cannot be considered to be stablished beyond doubt.

B. Theromorphoid trackways (PL XI). These are quadrupedal tracks, with a medium pace angulation. The footprints are of elliptical outline, the largest axis transverse to the mid-line. The claws are partially or completely separated from the palm or the sole pad and are sometimes modified into hooves. The stride is between $15 \mathrm{~cm}$ and $50 \mathrm{~cm}$. Eigth to ten different types are found. Since the age of the Botucatu Formation is almost certainly Jurassic (sew below), these footprints present a difficult problem. They had been Permian or Triassic, they might easily have been accounted for as the footprints of therapsids footprint Laoporus. However, their late date makes such an interpretation difficult. The opinion of the authors is that they are footprints of a late-surviving group of mammal-like reptiles, the Tritylodontoloidea (Fourie 1962, 1968, Ginsburg 1961,1962).

C. Mammaloid trackways (PI. XII). About ten trackways forms can be attributed to this morphological group. The most common is that of an animal of small size, with very small hands and much larger feet. The imprints frequently show primary overlap, either marginal or total, and overstep is always absent. The pace angulation is relatively high for a quadruped (up to $160^{\circ}$ ). The foot has an elliptical outline, its major axis transverse and the anteroposterior axis inclined slightly inward. The toes are short, clawless, with a probable phalangeal formula $2-3-3-3-3$, the fifth toe being bigger than the others and showing a slight adbuction; however, sometimes only four toes (II -V) are impressed. The hands are very small and roundish. There is no sign of tail drag. These trackways have been attributed to a new parataxon, Brasilichnium elusivum Leonard! 1981, tentatively interpreted as the track of an early mammal. A similar track is illustrated at plate XII. A. Normally these tracks indicate a walking gait, but galloping tracks are also encountered (PI. XII.E). Other mammaloid trackways belong to small, hopping animals. These are rare and hard to attribute, but are strikingly reminiscent of the trackways of hopping Rodentia, seen in the dunes of North Africa and Sinai Desert of today. Whether these mammaloid trackways are those of true mammals or those of mammal-like reptiles is a question that cannot be answered satisfactorily in view of the still uncertain age of the Botucatu Formation and the small amount of information yet available concerning the morphology of the limbs of protomammals. The authors have considered the foot morphology and gailt of these animals close to the reptile-mammal transition. Early Mesozoic mammaloid footprints are otherwise unknown, the oldest reported footprint of this type from another locality being from the Middle Jurassic Stonefield Slate of England (Sarjeant 1975), and from the Oxfordian of Patagonia (Casamiquela 1964).

\section{COMPARATIVE STRUCTURE OF THE ARGEN- TINEAN AND BRAZILIAN ICHNOFAUNAS}

Triassic Argentinean Ichnofaunas Las Higueras (Middle to Upper Triassic). Three forms with nine individuals attributable to Theriodontia; one individual of Chirotherium hiquerense; a set of incomplete footprints attributable to prosauropodians or to Chirotherium. It is an ichnofauna with a large predominance of therapsids, as for the number of individuals $(81.8 \%)$; and a minority of quadrupedal archosaurians. No mammals.

Campo de Ischigualasto (Upper Landinian). Two individuals of Rigalites ischiqualastianus, attributed to quadrupedal thecodonts. It is a totally quadrupedal archosaurian ichnofauna.

Quebrada Los Rastros (Lower Carnian). One individual of Rigalites ischigualastianus.

Rio Los Tarros - Sur Pagancillo (Upper Triassic). Nine individuals, probably of the same form, attributable to Chirotherium sp.; one small footprint of the dinosauroid group, bipedal, tridatyl, attributable to a thecodont to a dinosaurian; no therapsidians; no mammals. It is an ichnofauna that includes a majority of quadrupedal thecodonts (64.3\% of the individuals); and a minority of bipedal archosaurians. It is an exclusively archosaurian fauna, but with just one lacertoid footprint.

Los Menucos (Norian to Lower Rhaetian). Six forms of therapsids, with 46 individuals all together: Gallegosichnus garridoi and cf. G. garridoi (16 individuals; 34.8\%); Calibarichnus ayestarani $(1 ; 2.2 \%)$; Palaciosichnus zettii $(1$; $2,2 \%)$; Rogerbaletichnus aguilerai (2; 4.4\%); (all these taxa were instituted by Casamiquela 1964); Stipanicichnus bonettii Casamiquela $1975 \mathrm{a}(1 ; 2.2 \%)$; the unnamed form of the MACN 18198 specimen (4; 8.7\%); another theromorphoid form $(11 ; 24 \%)$; one form of quadrupedal thecodont: Shimmelia chirotheroides Casamiquela 1964 (2; 4.4\%); two bipedal trackways perhaps attributable to Prosauropoda (2; 4.4\%); two mammaloid forms attributable to mammals or to Theriodontia $(5 ; 10.9 \%)$; one unclassifiable form with sprawling gait: Ingenierichnus serrai Casamiquela 1964 (1: $2.2 \%)$. It is a large ichnofauna of 46 individuals with large predominance of therapsids (36 individuals, $78.3 \%$ of the individuals; 6 forms, $54,5 \%$ of the forms). Among them, Gallegosichnum garridoi and cf. G. garridoi has 16 individuals $(34.8 \% ; 44.4 \%$ of the therapside). The second place is for mammaloid trackways ( 5 individuals, $10.9 \% ; 2$ forms, $18.2 \%$ ). The third place is for the archosaurs (4 individuals, $8.6 \% ; 2$ forms, $18.2 \%$ ). It is a theropsidian fauna (89.2\% of individuals; $72.7 \%$ of the forms) with a few archosaurians.

Jurassic Argentinean Ichnofaunas Estância Laguna Manantiales (Upper Jurassic, Probably Oxfordian). No therapsids and no thecodonts. Four forms of dinosaurs, three of them bipedal: Wildesichnus navesi (biped; 21 individuals; 9.9.\%); Sarmientichnus scagliai (biped; 16; 7,5\%); Delatorrichnus goyenechei (quadrupedal; 19; 9\%); an unnamed form (biped; $1 ; 0.5 \%$ ); one form attributed to early mammals: Ameghinichnus patagonicus $(155 ; 73.1 \%)$. It is a large ichnofauna with 212 individuals, with an evident predominance of mammalian individuals $(73.1 \%)$. However, small dinosaurian individuals are abundant $(57 ; 26.9 \%)$, Bipedal dinosaurs are represented by 38 individuals (17.9\%). As for the form number, dinosaurs predominate with four forms $(80 \%)$. 
Brazilian Ichnofauna (Botucatu Formation) Araraquara (discussed age). For statistical purpose, 100 slabs (ARSB 5 to ARSB 149) were chosen; within them one finds: seven theromorphoid forms, with eight individuals, attributable to Theriodontia (TTritylodontoidea) ( $7.7 \%$ of the individuals; 29.2 of the forms) eight dinosauroid forms (all bipedal) with 29 individuals, attributable to bipedal dinosaurs and/or to bipedal thecodonts, depending on the age of the Botucatu Formation; nine mammaloid forms with 67 individuals. Among these, Brasilichnium elusivum presents 43 individuals (41.3\% of the sample; $64.2 \%$ of the mammaloids) No quadrupedal thecodonts. It is a large and varied ichnofauna of 104 individuals in which mammaloid individuals predominate $(64.4 \%)$; dinosauroid $(27.9 \%)$ and theromorphoid individuals $(7.7 \%)$ fill respectively the second and the third places. As for the forms numbers ( 24 forms in all) figures are respectively $37.5 \%, 33.3 \%$ and $29.2 \%$.

\section{COMPARISON AMONG ICHNOFAUNAS The}

comparison between the structure of the ichnofauna of the Botucatu Formation, Triassic and Jurassic ichnofaunas of Argentina can supply new data on the age of the Botucatu Formation and its ichnofauna. The five more important among the Triassic Argentinean ichnofaunas present, as for the individual numbers, the following characteristics (Tabs. 1 and 2):

1. Two of them present a large therapsidian majority, but three of them have no therapsids at all $(81.8 \%, 0 \%, 0 \%, 0 \%$, $78.3 \%$, Mean $(\mathrm{M})=32 \%$; absolute $\%(\mathrm{~A})=60.8 \%)$.

2. All of them include quadruped thecodonts $(13.7 \%, 100 \%$, $100 \%, 64.3 \%, 4.3 \%, \mathrm{M}=56 \% ; \mathrm{A}=20.9 \%$ ).

3. They include little or no dinosauroid material at all $(4.5 \%$, $0 \%, 0 \%, 7.1 \%, 4.3 \%, \mathrm{M}=3.2 \% ; \mathrm{A}=4.7 \%$ ).

4. Generally they do not present mammaloid trackways. This kind of material seem to begin in the very late Triassic terrains (Norian to Rhaetian) $(0 \%, 0 \%, 0 \%, 0 \%, 10.9 \%, \mathrm{M}=$ $2.2 \% ; \mathrm{A}=6.8 \%$ )

5. Quadrupedalism seems to be almost universal as for the individuals $(100 \%, 100 \%, 85.7 \%, 95.7 \%, \mathrm{M}=93.9 \%)$; as well as for the forms $(100 \%, 100 \%, 100 \%, 50 \%, 90.9 \% \mathrm{M}=$ $88.2 \%, \mathrm{~A}=93.9 \%$ ).

6. The therapsidian/archosaurian ratio $(32 \% / 58.4 \%) 0.55$, as for the percentual of individuals.

7. The mammal/archosaurian ratio is almost nil $(0.04)$, as for the percentual of individuals.

8. The therapsidian/archosaurian ratio is $(32.2 \% / 58.4 \%) 0.59$, as for the percentual of individuals.

On the contrary, the only Jurassic Argentinean ichnofauna presents the following characteristics:

1. No therapsidians $(0 \%)$.

2. No thecodonts, and specially no quadrupedal thecodonts $(0 \%)$.

3. The fauna includes a good deal of bipedal dinosaurs. The dinosauroid material includes $26.9 \%$ of the individuals and $80 \%$ of the forms; $17.9 \%$ of the individuals and $60 \%$ of the forms are bipedal.

4. One only mammaloid form (perhaps with three varieties, one of them overhelming) predominates as for the individuals number $(73.1 \%)$.

5. Quadrupedalism is rarer than in the Triassic with $82.1 \%$ of the individuals and only $40 \%$ of the forms, but is always strong.

6. The therapsidian/archosaurian ratio (which is also the mammal/archosaurian ratio) is $(73.1 \% / 26.9 \%) 2.72$, as for the percentual of individuals.

The situation as for the Araraquara ichnofauna is as follows:

1. It includes a small number of therapsid individuals, but a large number of forms (7.7\% of the individuals and $29.2 \%$ of the forms).

2. No quadrupedal thecodonts $(0 \%)$.

3. It includes a good percentual of dinosauroid trackways as for the individual percentual $(27.9 \%)$, more or less as at Estância Laguna Manantiales; however the forms percent is lower than of that locality $(33.3 \%)$.

4. The mammal percentual is high, but not so high as at Estância Laguna Manantiales, as for the individuals (64,4\% against $73.1 \%$ ); it is higher than at Estância Laguna Manantiales as for the forms (37.5\% against 20\%).

5. 63 trackways and 14 forms are quadrupedal; 41 trackways and ten forms are bipedal. In this ichnofauna, where a number of mammaloid trackways present hopping gait, bipedalism is rather common $39.4 \%$ of the individuals and $41.7 \%$ of the forms), and quadrupedalism rate is relatively low (60.6\% of

Table I - The ichnofaunas of the Triassic and Jurassic of Argentina and the ichnofauna of the Botucatu Formation of Araraquara (Brazil). The table shows the number of the units (N), the percentages (\%) of the forms $(F)$ and the individuals (I) of the ichnofaunas

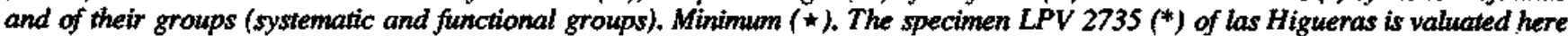
as 0,5 in two squares because of is doubtful classification; it is necessary to remember that it is a quadrupedal archosaurian

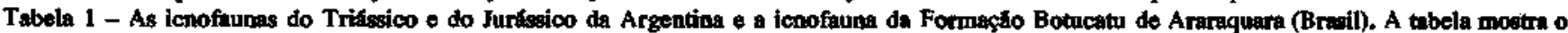

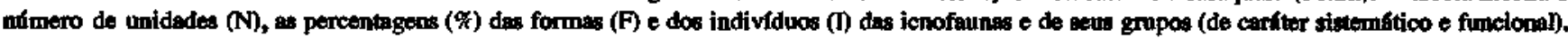

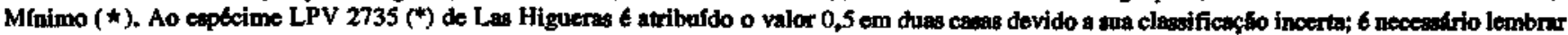
que se trate de um arcoseanro quadrípode

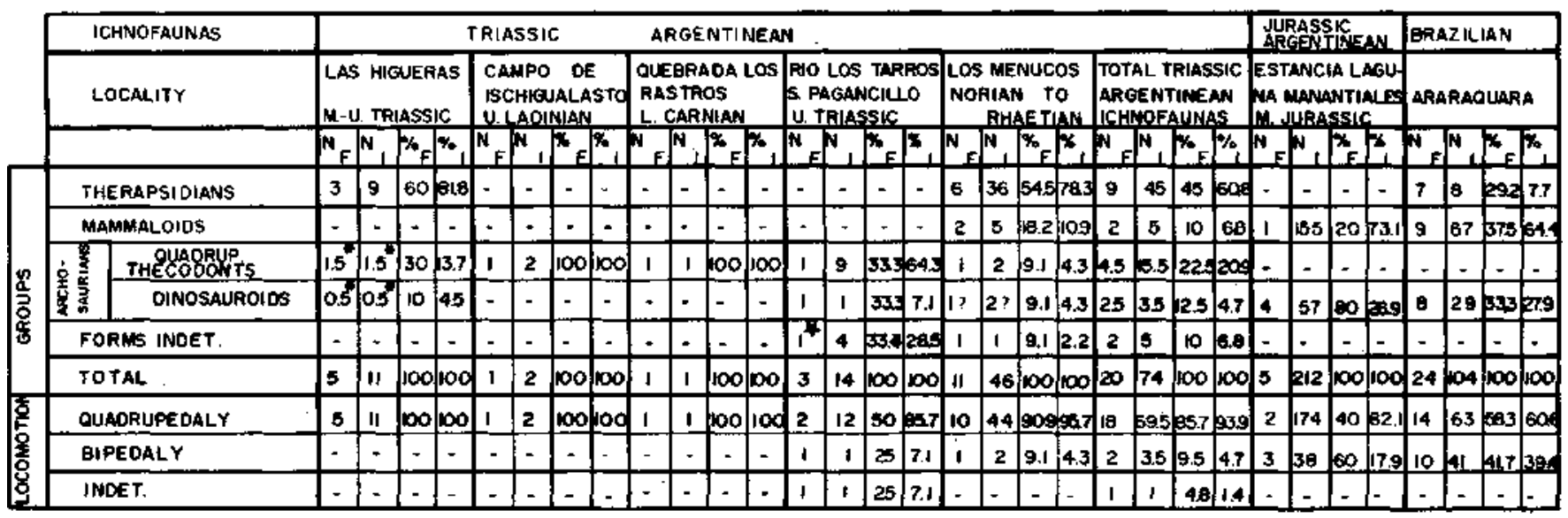


Table 2 - The table compares the structures of the ichnological association and their numerical values. The column "TRENDS" shows graphically the behaviour of the data, for example the increase or decrease of the number of forms and individuals from Triassic to Jurassic. The column "AGE' points to the meaning of the data for the dating of the Botucatu Formation Tabela 2 - A tabela compara as estruturas das associações icnológicas e seus valores numéricos. A coluna "TRENDS" (tendências) mostra graficamente o comportamento dos dados, por exemplo, o aumento ou a diminuição do número de formas e indivíduos do Triássico ao Jurássico. A coluna "AGE" (idade) indica o significado dos dados para a datação da Formação Botucatu

\begin{tabular}{|c|c|c|c|c|c|c|c|}
\hline & \multicolumn{2}{|l|}{ GROUPS } & $\begin{array}{l}\text { TRIASSIC } \\
\text { ARGENTINEAN } \\
\text { LOCALITIES } \\
\end{array}$ & $\begin{array}{l}\text { JURASSIC } \\
\text { BRAZILIAN } \\
\text { LOCALITY } \\
\end{array}$ & $\begin{array}{l}\text { JURASSIC } \\
\text { ARGENTINEAN } \\
\text { LOCALITY }\end{array}$ & TRENDS & $A G E$ \\
\hline 1 & \multicolumn{2}{|c|}{ THERAPSIDIANS } & $\pi=32 \%$ & $7.7 \%$ & $0 \%$ & $\operatorname{Tr} \supseteq \mathrm{J}$ & $T r / S$ \\
\hline 2 & \multicolumn{2}{|c|}{ QUADRUP. THECODONTS } & $\bar{M}=56 \%$ & $0 \%$ & $0 \%$ & $\mathrm{Tr}=\mathrm{J}$ & $+J$ \\
\hline 3 & \multicolumn{2}{|l|}{ DINOSAUROIOS } & $\bar{M} \cdot 3.2 \%$ & $27.9 \%$ & $26.9 \%$ & $\operatorname{Tr} \rightleftharpoons \mathrm{J}$ & $+J$ \\
\hline 4 & \multicolumn{2}{|l|}{ MAMMALOIDS } & $\overline{\mathbf{M}}=2.2 \%$ & $64.4 \%$ & $73.1 \%$ & $\Longrightarrow \mathrm{J}$ & $+J$ \\
\hline \multirow{4}{*}{5} & \multirow{2}{*}{ QUADRUPEDALY } & FORMS & $=85.7 \%$ & $58.3 \%$ & $40 \%$ & $\mathrm{Tr}=\mathrm{J}$ & $+J$ \\
\hline & & INOIV. & $\mathbf{n}=93.9 \%$ & $60.6 \%$ & $82.1 \%$ & $T r \smile J$ & $+J$ \\
\hline & \multirow{2}{*}{ BIPEDALY } & FORMS & $\mathbf{M}-9.5 \%$ & $41.7 \%$ & $60 \%$ & $\angle \mathrm{J}$ & $+\mathrm{J}$ \\
\hline & & INDIV. & $\overline{\mathrm{M}}=4.7 \%$ & $39.4 \%$ & $17.9 \%$ & $\operatorname{Tr} \cap \mathrm{J}$ & $+J$ \\
\hline 6 & \multicolumn{2}{|c|}{ THERAPSIOIANS/ARCHOSAURIANS } & 0.55 & 0.28 & 0 & $T r=\mathrm{J}$ & $\mathrm{Tr} / \mathrm{J}$ \\
\hline 7 & \multicolumn{2}{|c|}{ MAMMALOIOS/ARCHOSAURIANS } & 0.04 & 2.31 & 2.72 & $\mathrm{Tr} \simeq \mathrm{J}$ & $+\mathrm{J}$ \\
\hline 8 & \multicolumn{2}{|c|}{ THEROPSIDIANS/ARCHOSAURIANS } & 0.59 & 2.58 & 2.72 & $\mathrm{Tr} \rightleftharpoons \mathrm{J}$ & $+J$ \\
\hline
\end{tabular}

the individuals and $58.3 \%$ of the forms).

6/8. The therapsidian/archosaurian ratio is medium (0.28); the mammal/archosaurian ratio (231) and the therapsidian/ archosaurian ratio (2.58) are high.

CONCLUSION ON THE AGE OF THE BOTUCATU FORMATION In spite of the difficulties coming from the very different number of the individuals examined by the authors (from 1 to 212), as well as from the differences of environment and geographic distance, the data allow the authors to point out the following results (Tab. 2): the ichnofauna of the Botucatu Formation, in Araraquara, seems to fit in intermediate position between the Triassic and Jurassic ichnofaunas of Argentina, with a greater Jurassic affinity. The items 1 and 2 of the table 2 show a progressive diminution of therapsids an of quadruped thecodonts from Triassic to Jurassic, passing through the ichnofauna of Araraquara. The items 4, 6 and 7 show a gradual increase of mammaloid forms, both in absolute meaning and in number of archosaurs, with the great increase of mammals, increase also the amount of therapsids, notwithstanding the diminution and later disappearance of therapsids.

The situation is not clear with reference to items 3 and 5 . In item 3 the percentage of dinosauroid individuals is lightly higher in Araraquara than in Estância Laguna Manantiales; but refering to forms, the percentage becomes gradually different from Triassic faunas, passing through the fauna of Araraquara, till the Argentinean Jurassic fauna (10\% - 33.3\% $-80 \%)$. In item 5, the bipedaly $\wedge$ is higher in Araraquara than Estância Laguna Manantiales, considering all bipedal trackways, including those that do not represent habitually bipedal animals, but apparently quadruped mammals while resting, or going after hunt, or feeding, that go with a jumping gait when running away, perhaps just to adapt to a dune-desert environment. Also today deserts have many animals of this kind. But if the authors consider only bipedal dinosauroid trackways, the ones that are bipedal sensu stricto the percentages are: Argentinean Triassic 2.3\%; Araraquara $29 \%$; Argentinean Jurassic $17.9 \%$ with reference to the number of bipedal dinosauroid forms, their percentages increase gradually Argentinean Triassic 10\%: Araraquara $33.3 \%$; Argentinean Jurassic 60\%. On the other hand, the structure of Araraquara association seems generally nearer to that of Jurassic fauna than to those of Triassic faunas, as could be observed in items from 2 to 7 . The only item that seems to indicate more Triassic than Jurassic affinity values is the presence of a comparatively high number of theromorphoid trackways in the Botucatu Formation (7.7\%). Facing the clear Jurassic aspect pointed out all the others items (2-7), this fact may be explained, for the moment, in two ways:

1. These trackways must be attributed either to one or the other of the Triassic infraorders of Theriodontia suborder, and particularly, to the Cynodontia is Owen 1860. In this case the Araraquara fauna ought to be dated to the Uppermost Triassic (Rhaetian); a Lowermost Jurassic age might be accepted (Hettangian), if the authors deem likely a hypotetical loitering of a group of cynodonts or other theriodonts, in special, arid highland environment, geographically and ecologically isolated.

2. The trackways could be attributed to a population of medium/large-sized Tritylodontoidea (or Tritylodontidae); some of them with relatively gigantic size of forms, such as for example Tritylodontoideus maximus Fourie 1962, of the Cave Sandstone, Uppermost Triassic of South Africa. In this case the Araraquara fauna could be dated back to Early or Middle Jurassic, since this group, at least in Europe, got till the Bajocian at the very least.

In conclusion, the Botucatu Formation, at least in outcrops of State of São Paulo and particularly in the Araraquara area might be put into a period of time between the Rhaetian and Middle Jurassic, with greater probability for the Lower Jurassic or the Lowermost section of Middle Jurassic. 
Acknowledgements The authors express their sincere appreciation to all whe helped in the field, authorized the examinations of collections and the publication of the resulting data, furnished authors with original data and discussed about the subject. We specially wish to thanks:

1. From Argentina: Dr. Rodolfo M. Casamiquela, Mr. Horácio Magneres and Mr. Eulice Inostrosa (Fund. Ameghino, Viedma, Rio Negro); Prof. José Salfity and Prof. Ricardo N. Alonso (Dept. of Geology, Univ. of Salta); Dr. José F. Bonaparte, Prof. Wolfgang Volkheimer and Miss Cristina Lampugnani (Mus. Argent, de Cienc. Nat., Buenos Aires); Dr. Zulma B. de Gasparini, Mr. Marcello A. Reguero and the laboratory technicians (Dept. of Vert. Paldeont., Mus. of La Plata); Mr. Argentino A. Garrido (Intendente
"Municipal), Prof. Susana Dutto and Mr. Agustin Tscherig (owner of Tscherig Quarry) (all of them from Los Menucos, Rio Negro); Dr. Florencio G. Acenoleaza and Dr. James E. Powell (Fund. Miguel Lillo, San Miguel de tucumán).

2. From Brazil: Prof. Dr. Thomas R. Fairchild (Inst. of Geol. Sci., Univ. of São Paulo); Mr. Osvaldo and José F. Grosso (owners of the São Bento Quarry, Araraquara, São Paulo); Miss Kátia da S. Duarte (who typed this manuscrist). The eleven years of field, laboratory and library research which led to these conclusion were financed and encouranged by the Conselho Nacional de Desenvolvimento Científico e Tecnológico (CNPq); the Departamento Nacional e Produção Mineral (DNPM) officials gave their moral support, supply and transport.

\section{REFERENCES}

CASAMIQUELA, R.M. 1964. Estúdios Icnológicos - Problemas y Métodos de la fcnologia con Apücaríón cã Estúdio de Pisadas Mesozoicas (ReptiUa, Mammalia) de Ia Patagônia. Buenos Aires, Colégio Industr. Pio IX. 229p.

CASAMIQUELA, R.M. 1975a. Nuevo material y reinterpretación de Ia icnitas mesozoicas (Neotriásico) de los Menucos, Província de Rfo Negro (Patagônia). In: I CONGR. ARGENTINO PALEONT. BIOESTRAT., Tucumán, 1974. Ac/os... Tucumán, Asoc. Paleont. Argentina, v.1, p. 555-580.

CASAMIQUELA, R.M. 1975b. Sobre la signification de Ameghinichnus patagonicus, um mamífero brincador dei Jurásico Médio de Santa Cruz (Patagônia). In: I CONGR. ARGENTINO PALEONT. BIOESTRAT., Tucumán, 1974. Actas... Tucumán, Asoc. Paleont. Argentina, v.2, p. 71-85.

CORDANI, U.G. \& VANDOROS, P. 1967. Basaltic rocks of the Paraná basin. In: BIGARELLA, J.J. et al. Problems in brazilian gondwana geology. Curitiba, CNPq. p.207-231.

ELLENBERGER, P. 1976. Une piste avec traces de soies épaisses dans les Trias Inférieur à Moyen de Lodève (Hérault, France): Cynodontipus pofythrix nov. gen. nov. sp., Les Cynodontes en France. Géobios, 9(6):769-787.

FOURIE, S. 1962. Notes on a new tritylodontid from the cave sandstone of South Africa. Navorsinge van die Nasionale Museum.,

FOURIE, S. 1968. The jaw articulation of Tritylodontoideus maximus. South Africa Jour. Sci., 64(6):255-265.

GINSBURG, L. 1961. Un nouveau tritylodonte du Trias Superieur du Basutoland. CM. Acad. Sci. Paris, 252:3853-3854.

GINSBURG, L. 1962. Les tritylodontes. CoBoques Internat. C. N. R. S. Paris, 104:187-192.

HUENE, F.F. 1931a. Verschiedene Mesozoische Wirbeltierreste aus Südamerika. N. Jb. Min. Geol. Palaont., 66(8): 181 - 198.

HUENE, F.F. 1931b. Die Fossilen Fahrten im Rhãt von Ischigualasto in Nordwest-argentinien. Palaeobiologica, 4:99-112.

LEON ARDI, G. 1977. On a new occurrence of tetrapod trackways in the State of São Paulo, Brazil. Dusenia. 10(3): 181-183.

LEONARDI, G. 1980. On the discovery of an abundant ichnofauna (vertebrates and invertebrates) in the Botucatu Formation sj. in Araraquara, São Paulo, Brazil. An. Acad. bras. Ciênc. 52(3):559-567

LEONARDI, G. 1981 Brasilichnium elusivum gen. n., sp. n.: pistas de tetrapóde mesozóico guardadas nas coleções do Museu Nacional do Rio de Janeiro. An. Acad. bras. Ciênc., 53(4):793-805.

LEONARDI, G. \& GODOY, L.C. 1980. Novas pistas de tetrapódes na Formação Botucatu no estado de São Paulo. In: CONGR. BRÁS. GEOL., 31, Camborid, 1980. Anais... Camboriú, SBG. v.5, p.3080-3089.

LEONARDI, G. \& SARJEANT, W.A.S. 1986. Footprints representing a new mesozoic vertebrate fauna from Brazil. Modern Geology, 10:73-84.

RUSCONI, C. 1952. Rastros de patas de reptiles permicos de Mendoza. Rev. Hist, y Geogr de Cuyo 3(3):43-54.

SANFORD, R.M. \& LANGE, F.W. 1960. Basin study approach to oil evaluation of Paraná miogeosyncline of South Brazil. Bull. Amer. Assoc. Petrol. Geol. 44(8): 1316-1370.

SARJEANT, W.A.S. 1975. A vertebrate footprint from stonesfield slate (Middle Jurassic) of Oxfordshire. Mercian Geologist, 5(4):273-277.

URIEN, C.M. 1981. The basins of Southeastern South America (Southern Brazil, Uruguay \& Eastern Argentina) including the Malvinas Plateau and Southern South Atlantic paleogeographic evolution. In: VOLKHEIMER, W. \& MUSACCLIO, E.A. ed. Cuencas Sedimentares del Jurásico de America de Sur. Buenos Aires, v.1, p.45-125.

MANUSCRITO A568 Recebido em 29 de julho de 1988 Revisão do autor em 19 de janeiro de 1990 Revisão aceita em 15 de março de 1990 